\title{
In-situ observation of Asian pollution transported into the Arctic lowermost stratosphere
}

\author{
A. Roiger ${ }^{1}$, H. Schlager ${ }^{1}$, A. Schäfler ${ }^{1}$, H. Huntrieser ${ }^{1}$, M. Scheibe ${ }^{1}$, H. Aufmhoff ${ }^{1,2}$, O. R. Cooper ${ }^{3}$, H. Sodemann S, $^{4}$, \\ A. Stohl ${ }^{4}$, J. Burkhart ${ }^{4}$, M. Lazzara ${ }^{5}$, C. Schiller ${ }^{6}$, K. S. Law ${ }^{7}$, and F. Arnold ${ }^{2,1}$ \\ ${ }^{1}$ Deutsches Zentrum für Luft- und Raumfahrt, Institut für Physik der Atmosphäre, Oberpfaffenhofen, Germany \\ ${ }^{2}$ Max-Planck-Institute of Nuclear Physics, Atmospheric Physics Division, Heidelberg, Germany \\ ${ }^{3}$ Cooperative Institute for Research in Environmental Sciences, University of Colorado/NOAA Earth System Research \\ Laboratory, Boulder, USA \\ ${ }^{4}$ Norwegian Institute for Air Research (NILU), Kjeller, Norway \\ ${ }^{5}$ Space Science and Engineering Center, University of Wisconsin-Madison, Madison, USA \\ ${ }^{6}$ Forschungszentrum Jülich, IEK-7: Stratosphere, Germany \\ ${ }^{7}$ UPMC Univ. Paris 06; Univ. Versailles St-Quentin; CNRS/INSU, LATMOS-IPSL, Paris, France \\ *now at: Institute for Atmospheric and Climate Science, ETH Zürich, Switzerland
}

Received: 4 May 2011 - Published in Atmos. Chem. Phys. Discuss.: 31 May 2011

Revised: 7 October 2011 - Accepted: 24 October 2011 - Published: 7 November 2011

\begin{abstract}
On a research flight on 10 July 2008, the German research aircraft Falcon sampled an air mass with unusually high carbon monoxide (CO), peroxyacetyl nitrate (PAN) and water vapour $\left(\mathrm{H}_{2} \mathrm{O}\right)$ mixing ratios in the Arctic lowermost stratosphere. The air mass was encountered twice at an altitude of $11.3 \mathrm{~km}, \sim 800 \mathrm{~m}$ above the dynamical tropopause. In-situ measurements of ozone, NO, and $\mathrm{NO}_{\mathrm{y}}$ indicate that this layer was a mixed air mass containing both air from the troposphere and stratosphere. Backward trajectory and Lagrangian particle dispersion model analysis suggest that the Falcon sampled the top of a polluted air mass originating from the coastal regions of East Asia. The anthropogenic pollution plume experienced strong uplift in a warm conveyor belt (WCB) located over the Russian east-coast. Subsequently the Asian air mass was transported across the North Pole into the sampling area, elevating the local tropopause by up to $\sim 3 \mathrm{~km}$. Mixing with surrounding Arctic stratospheric air most likely took place during the horizontal transport when the tropospheric streamer was stretched into long and narrow filaments. The mechanism illustrated in this study possibly presents an important pathway to transport pollution into the polar tropopause region.
\end{abstract}

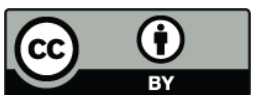

Correspondence to: A. Roiger (anke.roiger@dlr.de)

\section{Introduction}

Although located thousands of kilometres from major industrial regions, the Arctic troposphere is polluted by the import of anthropogenic emissions (e.g. Law and Stohl, 2007). Pollution enters the Arctic mainly during winter and spring by long-range transport (LRT) from the industrial regions of North America, Europe and Asia. Models even suggest a year-round import from the northern mid-latitudes, with source regions varying with season (Eckhardt et al., 2003; Klonecki et al., 2003; Stohl, 2006; Shindell et al., 2008). However, large uncertainties remain regarding the transport pathways, and the relative contributions of different source regions. One objective of the POLARCAT project (http://www.polarcat.no) was to combine both aircraft and satellite observations with models in order to study the role of long-range poleward transport of trace gases and aerosols on climate change in the Arctic.

Depending on the source region, anthropogenic emissions may reach the Arctic through several transport patterns. According to Stohl (2006), pollution from Asia and North America enters the Arctic mainly at higher altitudes, as relatively warm and moist mid-latitude air masses ascend over colder, denser arctic air masses; followed by descent within the Arctic or transport back to lower latitudes. The necessary up-lift of industrial emissions from the boundary layer to the middle and upper troposphere efficiently takes place within so-called warm conveyor belts (WCBs) (e.g. Stohl

Published by Copernicus Publications on behalf of the European Geosciences Union. 
and Trickl, 1999; Stohl, 2001; Cooper et al., 2002, 2004; Stohl et al., 2003). WCBs are defined as strongly ascending moist airstreams in extratropical cyclones that, on short time-scales of 1 or 2 days, rise from the boundary layer to the upper troposphere (e.g. Wernli and Davies, 1997; Eckhardt et al., 2004). The ascent is accompanied by an increase of potential temperature due to latent heat release from water vapour condensation, cloud formation, and a loss of moisture by precipitation. WCBs frequently entrain polluted air masses from the industrialized eastern seaboards of North America and Asia (Stohl et al., 2001; Wernli and Bourqui, 2002), with Asian WCBs experiencing stronger ascent (Wild and Akimoto, 2001; Stohl et al., 2002).

The export of Asian pollution is of great concern, since anthropogenic emissions in Asia have increased rapidly in recent years (e.g. Akimoto et al., 2003; Richter et al., 2005; Zhang et al., 2009). Measurements performed in the source region of Asian WCBs show extremely high mixing ratios of pollutants. In North East China, $\mathrm{CO}$ values of up to $1185 \mathrm{nmol} \mathrm{mol}^{-1}$ were measured in the warm sector ahead of a cold front, originating from the North China Plain (Ding et al., 2009). For similar meteorological conditions within developing WCBs, the CO mixing ratios are found to be about a factor of five higher in China as compared to the US (Dickerson et al., 2007). After up-lift within the WCB, the polluted Asian air masses are transported globally, predominantly by the westerly winds. Numerous airborne observations of Asian plumes have been conducted above the North American continent (e.g. Jaffe et al., 1999, 2003; Jaeglé et al., 2003; Hudman et al., 2004), and even above Europe (Stohl et al., 2007; Fiedler et al., 2009).

During LRT, the chemical composition of the polluted air masses is altered through chemical transformation (Jacob et al., 2003; Hudman et al., 2004; Singh et al., 2009) and mixing with surrounding air (Trickl et al., 2003; Stohl et al., 2007). Mixing processes may take place in the vicinity of fronts (Esler et al., 2003) or in the WCB outflow region (Cooper et al., 2002; Mari et al., 2004). Mixing with stratospheric air may also occur in the mid- and upper troposphere (Parrish et al., 2000; Brioude et al., 2007; Stohl et al., 2007). In the extra-tropical UTLS (upper troposphere/lowermost stratosphere) region, large-scale stirring and inter-mingling of air masses leads to the formation of a mixing layer, and can be quantified using tracer relationships (Fischer et al., 2000; Zahn et al., 2000; Hoor et al., 2002, 2004; Pan et al., 2004, 2007; Kunz et al., 2009). Exchange across the extratropical tropopause plays an important role for the trace gas composition in the lowermost stratosphere, affecting both local chemistry and the radiative budget. It is therefore notable that Lagrangian transport climatologies show a potential for WCB trajectories to reach the tropopause region (Stohl, 2001; Wernli and Bourqui, 2002). A few percent of these trajectories even enter the lowermost stratosphere, not only within active WCBs, but also a few days after the WCBs decay (Eckhardt et al., 2004). Since some of the WCBs reach polar latitudes, it is conceivable that anthropogenic pollution can be transported into the polar lowermost stratosphere within a few days after emission. This transport pathway has not yet been verified by observations, however, measurements show in general relatively high $\mathrm{CO}$ mixing ratios of $100 \mathrm{nmol} \mathrm{mol}^{-1}$ and more in the polar lowermost stratosphere (Cooper et al., 2005; Tilmes et al., 2010).

In the present paper we demonstrate that Asian pollution can reach the Arctic tropopause region within a few days after emission. To the best of our knowledge, our study presents the first in-situ observation of a distinct Asian pollution plume recently transported into the Arctic lowermost stratosphere. The anthropogenic emissions were up-lifted within a warm conveyer belt over eastern Russia, transported across the Arctic and probed by the Falcon above northern Greenland, where it was already mixed with stratospheric air. The aim of this paper is to present in-situ trace gas observations, to analyze the origin of the encountered air mass, and to discuss its lifting process and transport history.

The present paper is organized as follows: Sect. 2 describes the methods used in the analysis. A detailed description of the case study is given in Sect. 3, beginning with a presentation of the meteorological situation at the time of our measurements (Sect. 3.1) and a discussion of the in-situ observations (Sect. 3.2). Subsequently, the source region of the encountered air mass is identified by using a Lagrangian particle dispersion model and a backward trajectory model (Sect. 3.3). The analysis of the meteorological situation in the source region (Sect. 3.4) as well as during transport to Greenland (Sect. 3.5) is followed by a discussion of tracer correlations (Sect. 3.6.1) and mixing processes that have occurred during the cross-polar transport (Sect. 3.6.2). Section 4 provides the summary and conclusions.

\section{Data and model descriptions}

\subsection{Chemical measurements}

The data presented in this paper were measured on 10 July 2008, on a flight with the DLR (Deutsches Zentrum für Luft- und Raumfahrt) Falcon research aircraft above northern Greenland. The flight was conducted within the framework of the GRACE campaign (Greenland Aerosol and Chemistry Experiment), a sub-project of the POLARCAT (Polar Study using Aircraft, Remote Sensing, Surface Measurements and Models, of Climate, Chemistry, Aerosols, and Transport) initiative. GRACE was conducted in summer 2008 (30 June18 July) and aimed to study the influence of both boreal forest fire and anthropogenic emissions on the composition of the troposphere and lowermost stratosphere in the summertime Arctic. During GRACE, the Falcon was based in Kangerlussuaq, Greenland $\left(67.01^{\circ} \mathrm{N}, 50.7^{\circ} \mathrm{W}\right)$. A total of 16 local flights were performed, covering latitudes from $57^{\circ} \mathrm{N}$ to $81.5^{\circ} \mathrm{N}$, longitudes from $66^{\circ} \mathrm{W}$ to $16^{\circ} \mathrm{E}$ and altitudes up 
to $11.8 \mathrm{~km}$. The Falcon was equipped with instruments to measure trace gases, aerosol microphysical properties as well as meteorological parameters. The present study focuses on the trace gas measurements. $\mathrm{CO}$ was detected by vacuumUV fluorescence (Gerbig et al., 1999; accuracy $\pm 5 \%$, detection limit $2 \mathrm{nmol} \mathrm{mol}^{-1}$ ), ozone by UV absorption (TEI49C; $\pm 5 \%, 1 \mathrm{nmol} \mathrm{mol}^{-1}$ ) and $\mathrm{CO}_{2}$ via an infra-red absorption technique (Li-COR 7000; $\pm 5 \%, 5 \mathrm{nmol} \mathrm{mol}^{-1}$ ). $\mathrm{NO}$ and the sum of oxidized nitrogen compounds, $\mathrm{NO}_{\mathrm{y}}$, were measured with a chemiluminescence detector (Ziereis et al., 2000; $\left.\pm 10 / 15 \%, 10 / 15 \mathrm{pmol} \mathrm{mol}^{-1}\right) . \quad \mathrm{NO}_{\mathrm{y}}$ species $\left(\mathrm{NO}_{\mathrm{y}}=\mathrm{NO}\right.$, $\mathrm{NO}_{2}, \mathrm{NO}_{3}, \mathrm{~N}_{2} \mathrm{O}_{5}, \mathrm{HNO}_{3}$, PAN...) hereby were first converted to $\mathrm{NO}$ at the surface of a gold converter by adding $\mathrm{CO}$ as reducing agent, and then detected as NO. Peroxyacetyl nitrate (PAN) measurements were performed with a Chemical Ionisation - Ion Trap Mass Spectrometer (Roiger et al., 2011; $\pm 10 \%, 25 \mathrm{pmol} \mathrm{mol}^{-1}$ ), and the $\mathrm{H}_{2} \mathrm{O}$ data shown in the present paper were obtained by a Lyman-alpha hygrometer (Zöger et al., 1999; $\pm 6 \%, 0.1 \mu \mathrm{mol} \mathrm{mol}^{-1}$ ).

\subsection{FLEXPART simulations}

For the analysis of all GRACE flights, the FLEXPART model was used in order to attribute anthropogenic and biomass burning pollution sources to the in-situ observations. FLEXPART is a Lagrangian particle dispersion model (Stohl et al., 2005, and references herein). For this study, it was driven with meteorological analyses from the European Centre for Medium-Range Weather Forecasting (ECMWF) with a $0.5^{\circ} \times 0.5^{\circ}$ resolution. FLEXPART includes a sub-grid scale convective transport scheme. Stochastic fluctuations are obtained by solving Langevin equations (Stohl and Thomson, 1999) and are superimposed on the grid-scale winds to represent transport by turbulent eddies. For $\mathrm{CO}, \mathrm{NO}_{2}$ and $\mathrm{SO}_{2}$, the EDGAR (Emissions Database for Global Atmospheric Research) version 3.2 emission inventory for the year 2000 (fast track) on a $1^{\circ} \times 1^{\circ}$ grid was used outside North America and Europe. Over Europe, the EMEP (European Monitoring and Evaluation Programme) emission inventory for the year 2005 with a resolution of $0.5^{\circ} \times 0.5^{\circ}$ was used and over most of North America, the inventory of Frost et al. (2006) for the year 1999. While such a merged emission data set contains methodological inconsistencies with regard to how the emissions have been derived, for the purpose of our study the higher resolution and more recent information offered by the regional inventories compared to the EDGAR data set more than outweigh that disadvantage. Previous experience with the 1995 EDGAR inventory has shown that Asian CO emissions are underestimated (probably by a factor of 2 or more), while American $\mathrm{CO}$ emissions may be overestimated. For the input of biomass burning emissions, hot spot locations are obtained daily from measurements made with MODIS onboard the Aqua and Terra satellites and are compared to a land-use inventory with $1-\mathrm{km}$ resolution. The emissions are estimated assuming an area burned of 180 ha per fire detec- tion. They depend on a parameterization based on biomass available for burning, the fraction actually burned, and emission factors, all dependent on land-use. Fire emissions were only distributed within the lowest $150 \mathrm{~m}$ of the boundary layer and fires burned for $24 \mathrm{~h}$ (Stohl et al., 2007). All pollution tracers underlie passive transport without involving removal processes. After a life-time of 20 days, the tracers are removed under the assumption that they become incorporated into the so-called atmospheric background (Sodemann et al., 2011).

The present study also uses FLEXPART backward simulations. These were started along the flight track every time the Falcon moved by 0.15 degrees in either longitude or latitude, or whenever the altitude changed by $10 \mathrm{hPa}$. For each release 60000 particles were followed backward in time for 20 days. The model output of such backward simulations consists of fields of emission sensitivities which can be multiplied with emission fields to yield maps of source contributions for passive tracers (Stohl et al., 2003). When spatially integrated, tracer mixing ratios are obtained, allowing to construct tracer time series along the flight path. We consider $\mathrm{CO}, \mathrm{NO}_{2}$ and $\mathrm{SO}_{2}$ separately for both anthropogenic and biomass burning pollution from Asia, North America and Europe. Further information is given by the fraction of particles remaining in the stratosphere during the last 20 days. For this, troposphere and stratosphere are distinguished based on a threshold of 2 PVU (potential vorticity units).

\subsection{LAGRANTO trajectories}

The Lagrangian Analysis Tool (LAGRANTO; Wernli and Davies, 1997) was used to investigate the origin of the observed air masses over Greenland. The calculations are based on three-dimensional wind fields of 6-hourly ECMWF operational analyses at a $1^{\circ}$ horizontal grid resolution. Several variables characterizing the physical state of the air parcels including potential temperature, specific humidity and potential vorticity were traced along the trajectory paths.

In this case we used two different set-ups of LAGRANTO to calculate forward and backward trajectories. 8-day backward trajectories were started close to the observation time on 10 July, 18:00 UTC. These were initialized at a constant pressure level within a box centered around the region where the pollution was sampled (see later Sect. 3.3.2). Additionally, a method to diagnose warm conveyor belt trajectories was used (Wernli and Davies, 1997), by selecting only boundary layer air parcels that ascend poleward to the upper troposphere and lowermost stratosphere over a short time period (see Sect. 3.4).

\subsection{Composite satellite images}

The Antarctic Meteorological Research Center (AMRC) provides Arctic composite satellite images every three hours, creating a total of eight images per day (Lazzara and 

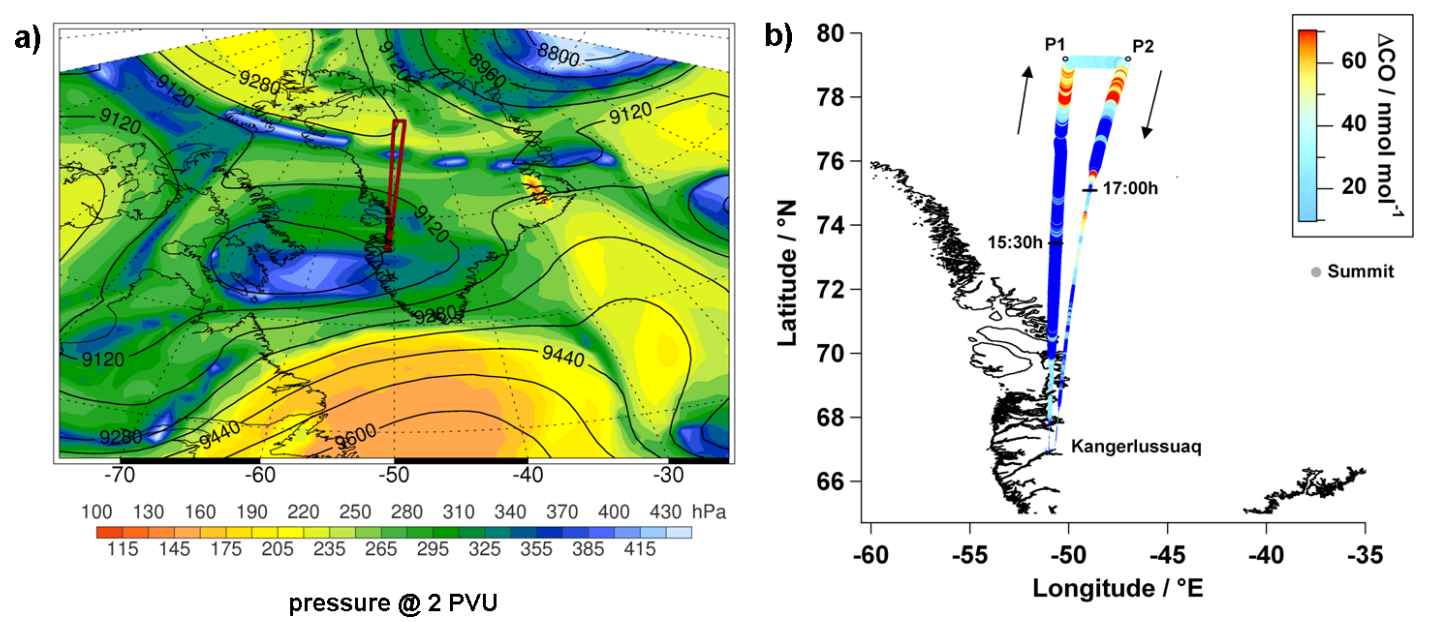

Fig. 1. (a) Flight path of the DLR Falcon on 10 July 2008 between $~ 14: 30$ UTC and 18:30 UTC (red line) superimposed on ECMWF analysis data at 18:00 UTC of pressure (colour shaded, $\mathrm{hPa}$ ) at the $2 \mathrm{PVU}$ (dynamical tropopause) surface and geopotential height at $300 \mathrm{hPa}$ (black lines, m). (b) Flight path, colour-coded by $\triangle \mathrm{CO}$ above altitude-dependent background values as derived from all GRACE data. Areas with $\Delta \mathrm{CO}<10 \mathrm{nmol} \mathrm{mol}^{-1}$ are shown in dark blue. North of approx. $77.5^{\circ} \mathrm{N}$, an air mass with enhanced $\mathrm{CO}$ mixing ratios was entered by the Falcon, both on the outbound and return leg at a constant flight level $(11.3 \mathrm{~km})$. The thickness of the line indicates the altitude (larger markers represent higher altitudes). For more details see text.

Knuth, 2011). Geostationary and polar-orbiting satellites are used to generate the composite and, depending on the geographical location, can include observations from the following: Polar Orbiting Environmental Satellite (POES), Geostationary Operational Environmental Satellites (GOESEast and GOES-West), Meteosat, Multi-function Transport Satellite (MTSAT-1R), Feng Yun-2 (FY-2), Kalpana-1, and Terra/Aqua. The source observations that are used in the composite are within plus or minus $50 \mathrm{~min}$ to the top of the synoptic hour, although most of the observations fall within a plus or minus $15-\mathrm{min}$ window. The imagery has the space background removed, and the data remapped into a polar stereographic projection. The data are merged with the geostationary observations combined first, followed by the polar orbiting observations. In general terms, the composite satellite images depict the temperature of the Earth as seen by the imagers on board the satellites, which measure the intensity of the radiation emitted by the Earth at approximately $11.0 \mu \mathrm{m}$, the infra-red window channel. The images are colour enhanced such that yellow and red colours highlight the cold upper-level cloud tops, green colours underscore the tops of the warmer mid-level and low-level clouds, and blue colours are the much warmer surface of the Earth. In the present paper, the composites are combined with overlays of the FLEXPART Asian anthropogenic $\mathrm{CO}$ tracer fields. The passive CO tracers with a life-time of 20 days were obtained from the FLEXPART forward model runs (see Sect. 2.2) and are represented in the satellite images by white contour lines.

Atmos. Chem. Phys., 11, 10975-10994, 2011

\section{Results and discussion}

\subsection{Meteorological situation at upper levels}

The weather situation close to the time of observation (10 July 2008, 18:00 UTC) is presented in Fig. 1a using $300 \mathrm{hPa}$ geopotential height (black isolines) and pressure altitude $p_{2 \mathrm{PVU}}$ of the dynamical tropopause, defined as the 2 potential vorticity units (PVU) surface (colour-coded). The red line gives the Falcon flight path. The geopotential height shows a large-scale trough over north-eastern Canada with a discrete low over the Davis Strait. The entire trough region is characterized by a low dynamical tropopause (equivalent to high values of $p_{2 \mathrm{PVU}}$, up to $\sim 400 \mathrm{hPa}$ within the closed contour line of the low). On its leading edge, the low has southerly flow at $300 \mathrm{hPa}$ (see geopotential isolines) and the dynamical tropopause is situated at $\sim 300 \mathrm{hPa}$. Above northern Greenland, north of a nearly east-west oriented narrow filament with a lower tropopause $\left(p_{2 \mathrm{PVU}}>400 \mathrm{hPa}\right)$, the dynamical tropopause is at higher levels $\left(p_{2 \mathrm{PVU}} \sim 230 \mathrm{hPa}\right)$. The associated air mass is located in the diffluent exit region of a jet. At this time the jet was located right over the pole, as shown by the widening spacing of geopotential isolines from the North Pole towards the most northern part of the 10 July flight.

\subsection{In-situ observations}

On the flight on 10 July 2008, CO values up to $138 \mathrm{nmol} \mathrm{mol}^{-1}$ were observed at $11.3 \mathrm{~km}$ altitude, whereas during GRACE typical $\mathrm{CO}$ mixing ratios at this altitude were $\sim 40$ to $50 \mathrm{nmol} \mathrm{mol}^{-1}$. Figure $1 \mathrm{~b}$ shows the 


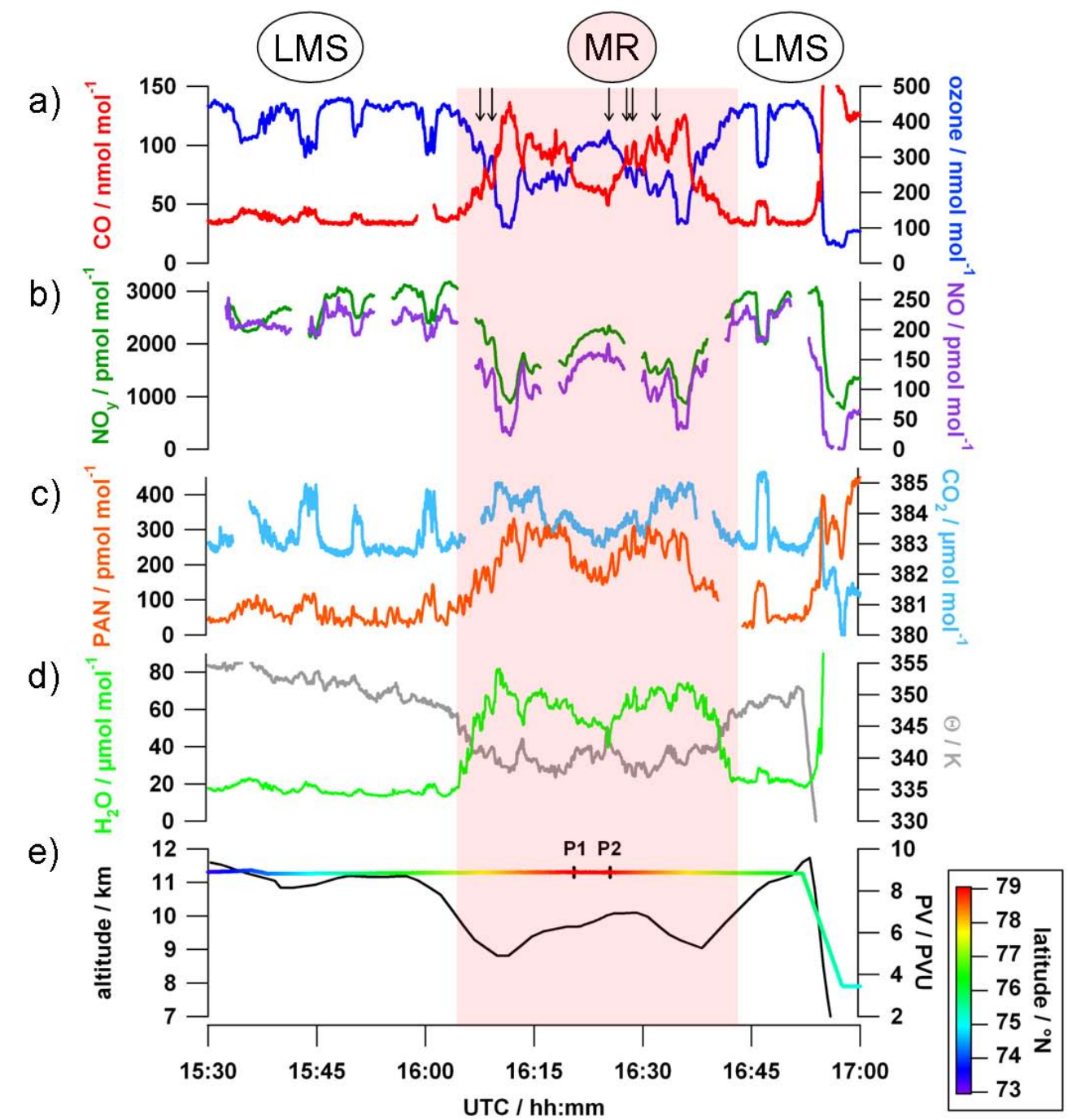

Fig. 2. Time series of measured trace gases for the GRACE flight on 10 July 2008, between 15:30 and 17:00 UTC. (a) $\mathrm{O}_{3}$ in blue and CO in red, (b) $\mathrm{NO}_{\mathrm{y}}$ in green and $\mathrm{NO}$ in purple, (c) PAN in orange and $\mathrm{CO}_{2}$ in light blue, (d) $\mathrm{H}_{2} \mathrm{O}$ in light green and potential temperature $\Theta$ in grey. Missing data correspond to internal calibration periods. (e) Flight altitude (latitude is colour-coded) and potential vorticity in black, as interpolated from the ECMWF analysis at 18:00 UTC. The flight segment discussed in the present study is highlighted in light red ("MR"), whereas the remaining data at this flight altitude are denoted by "LMS" (lowermost stratosphere). See text for more details.

Falcon flight-path, for illustration purposes it is colour-coded by the measured $\triangle \mathrm{CO}$ above the altitude-dependent $\mathrm{CO}$ background (see colour-scale on the top right). The CO background here is defined as the 30th percentile of all POLARCAT-GRACE measurements, calculated separately for altitude bins of $1 \mathrm{~km}$. $\Delta \mathrm{CO}$ values of $<10 \mathrm{nmol} \mathrm{mol}^{-1}$ are shown in dark blue. The marker size represents the flight altitude (larger markers indicate higher altitudes).

After take-off in Kangerlussuaq, the Falcon climbed up to $11.3 \mathrm{~km}$ altitude while flying north (up to point P1), and then $\sim 60 \mathrm{~km}$ to the east (towards point P2). On the way back to the south, the Falcon descended at $\sim 75.5^{\circ} \mathrm{N}$ to $7.9 \mathrm{~km}$ before landing again in Kangerlussuaq. The layer with enhanced $\mathrm{CO}$ was traversed twice, both on the outbound and the return leg, right before point $\mathrm{P} 1$ and after point $\mathrm{P} 2$. The maximum horizontal separation is $60 \mathrm{~km}$ ( $\mathrm{P} 1$ to $\mathrm{P} 2)$. Comparison with Fig. 1a shows that the layer with enhanced $\mathrm{CO}$ agrees well with the region of elevated tropopause, as indicated by the lower atmospheric pressure at the $2 \mathrm{PVU}$ surface.

Figure 2 presents the time-series for several trace gases for a part of the flight between 15:30 and 17:00 UTC (see time markers in Fig. 1b). It shows $\mathrm{CO}$ and $\mathrm{O}_{3}$ (a), $\mathrm{NO}$ and $\mathrm{NO}_{\mathrm{y}}$ (b) together with PAN and $\mathrm{CO}_{2}$ (c). Also given are the potential temperature $\Theta$ and the water vapour mixing ratio (d). The time resolution is $1 \mathrm{~s}$, except for PAN, which is reported every $2 \mathrm{~s}$. Panel e shows the flight altitude (colour-coded by the latitude of the Falcon), and potential vorticity as interpolated from the ECMWF analysis fields. The two way points 
$\mathrm{P} 1$ and P2 are marked as vertical lines (see Fig. 1b). The red shaded area in Fig. 2 highlights the flight segment with enhanced CO. In the following we will refer to this segment as mixing region "MR". The remaining data sampled at the same altitude, i.e. further south of "MR", are denoted by "LMS" (lowermost stratosphere).

When the Falcon entered the "MR", CO increased from about $40 \mathrm{nmol} \mathrm{mol}^{-1}$ up to $\sim 140 \mathrm{nmol} \mathrm{mol}^{-1}$ over a time span of $\sim 7 \mathrm{~min}$ (corresponding to $\sim 80 \mathrm{~km}$ ). The Falcon then observed a sharp decrease in $\mathrm{CO}$ down to $\sim 80 \mathrm{nmol} \mathrm{mol}^{-1}$, and a region of moderate $\mathrm{CO}$ values of $100 \mathrm{nmol} \mathrm{mol}^{-1}$ $(\sim 65 \mathrm{~km})$. At the most northern point, $\mathrm{CO}$ did not completely drop to mixing ratio values observed further south in the lowermost stratosphere ("LMS"), which indicates that the aircraft possibly did not traverse the entire mixing region. The time-series of the trace gases inside the "MR" is nearly symmetric due to its twofold sampling. The CO enhancement in the "MR" was accompanied by an increase of the tropospheric pollutant PAN (up to $\sim 330 \mathrm{pmol} \mathrm{mol}^{-1}$ compared to $\sim 40 \mathrm{pmol} \mathrm{mol}^{-1}$ in the "LMS"), and of water vapour $\left(\sim 80 \mu \mathrm{mol} \mathrm{mol}^{-1}\right.$ compared to $\sim 20 \mu \mathrm{mol} \mathrm{mol}^{-1}$ in the "LMS"). The trace gases with generally higher values in the stratosphere than in the unpolluted regions of the troposphere (i.e. $\mathrm{O}_{3}, \mathrm{NO}$ and $\mathrm{NO}_{\mathrm{y}}$ ) showed smaller mixing ratios within the "MR" of down to $100 \mathrm{nmol} \mathrm{mol}^{-1}, 30 \mathrm{pmol} \mathrm{mol}^{-1}$ and $900 \mathrm{pmol} \mathrm{mol}^{-1}$, respectively. The anticorrelation of the different trace gases indicates that the Falcon sampled an air mass of both tropospheric and stratospheric origin. The interpretation of the chemically inert greenhouse gas $\mathrm{CO}_{2}$ (atmospheric lifetime of $\sim 100 \mathrm{yr}$ ) however is more complicated, due to underlying temporal and spatial variations (see Sect. 3.6.1). In some parts of the "MR" some smaller scale filaments are observed (indicated by black arrows).

Thermodynamic parameters also vary within the "MR". Potential temperature $\Theta$ and potential vorticity both decrease, pointing to a less stable stratification in the "MR". Potential vorticity during this part of the flight had a minimum value of $\sim 5 \mathrm{PVU}$, and the minimum vertical distance between flight altitude and the 2 PVU tropopause was $\sim 800 \mathrm{~m}$ (see Sect. 3.5).

\subsection{Identification of source region}

\subsubsection{FLEXPART backward simulations}

The results of the FLEXPART backward runs initialised along the flight track are shown in Fig. 3b. To allow an easier comparison, the in-situ $\mathrm{O}_{3}$ and $\mathrm{CO}$ time-series are repeated in Fig. 3a. Generally, the structure of the "MR" is very well captured by the FLEXPART model. The blue line in panel $b$ gives the fraction of air with a stratospheric origin which decreases inside the "MR" to a minimum of $\sim 50 \%$. The red pattern in Fig. $3 \mathrm{~b}$ represents the Asian excess-CO, indicating that the tropospheric part of the encountered air mass was polluted by anthropogenic emissions of Asian origin. Ac- cording to the FLEXPART simulations, contributions from industrial pollution sources from other continents or from biomass burning are negligible.

The CO source contribution plot for 16:11 UTC (CO maximum) is given in Fig. 3c. This plot represents the product between the anthropogenic emission flux (taken from the emission inventories) and the footprint emission sensitivity. The latter is proportional to the residence time of the particles over a unit area in the lowest $100 \mathrm{~m}$ (Stohl et al., 2005). The CO source contribution plot shows that the pollution mainly originates from the North China Plain, one of the most densely populated regions in China, with some minor contributions from the North East China Plain and Korea. According to the model, the pollution was emitted approximately 6-10 days before our measurements (not shown).

\subsubsection{LAGRANTO backward trajectories}

In order to analyze the transport history of the sampled "MR" and "LMS" air masses, we calculated an ensemble of 8 day LAGRANTO backward trajectories. The results are illustrated in Fig. 4. A total of 242 trajectories were released in an area from $-60^{\circ} \mathrm{E}$ to $40^{\circ} \mathrm{E}$ and $75^{\circ} \mathrm{N}$ to $82^{\circ} \mathrm{N}$ (see black rectangle in Fig. 4a) at $217 \mathrm{hPa}$ on $10 \mathrm{July}, 18: 00$ UTC. The colour-code gives the latitude of the starting position and the black line within the rectangle shows the Falcon flight track. Figure $4 \mathrm{~b}$ to $d$ shows the temporal evolution of meteorological parameters along the trajectories (pressure, humidity, potential temperature).

We can mainly distinguish between two different air mass origins in this area. Trajectories in the southern part of the box were transported from northern North America towards Greenland, remaining above $300 \mathrm{hPa}$. These trajectories characterize the pathway for the sampled "LMS" air masses. The cyclonic curvature indicates transport within the large scale trough described in Sect. 3.1 (see also Fig. 1a). Trajectories in the northern part of the box were traced back across the North Pole to Siberia/Russia. Some parcels moved directly over the pole (yellow), while others were influenced by the upper level high that caused an anti-cyclonic rotation (blue and green).

The time series of pressure along the trajectories shows that independent of their origin, most of the parcels were transported at high altitudes above $300 \mathrm{hPa}$ (see Fig. 4b). Their PV values were predominantly larger than 2 PVU which points to stratospheric transport (not shown). Only a small number of the trajectories experienced a strong vertical displacement. Remarkably, three of these parcels (thick grey lines in Fig. 4) originate from the boundary layer in the industrialized coastal regions of China and Korea, where they had the possibility to take up anthropogenic pollution. This is in good agreement with the results of the FLEXPART analysis (see Sect. 3.3.1). The subsequent fast and strong ascent from ground level to the upper troposphere is accompanied by a strong loss of humidity and an increase of the potential 
a)

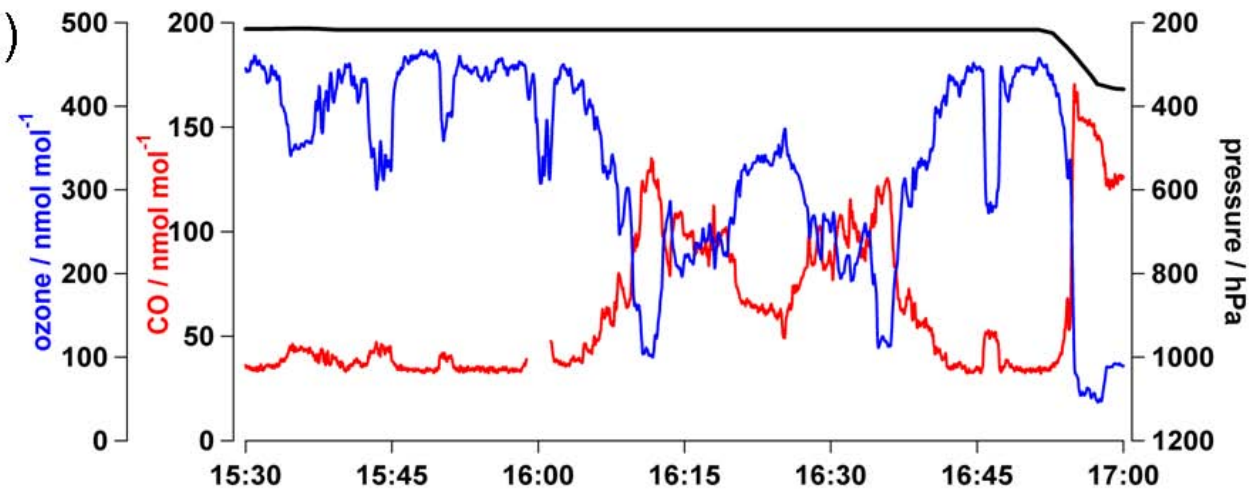

b)

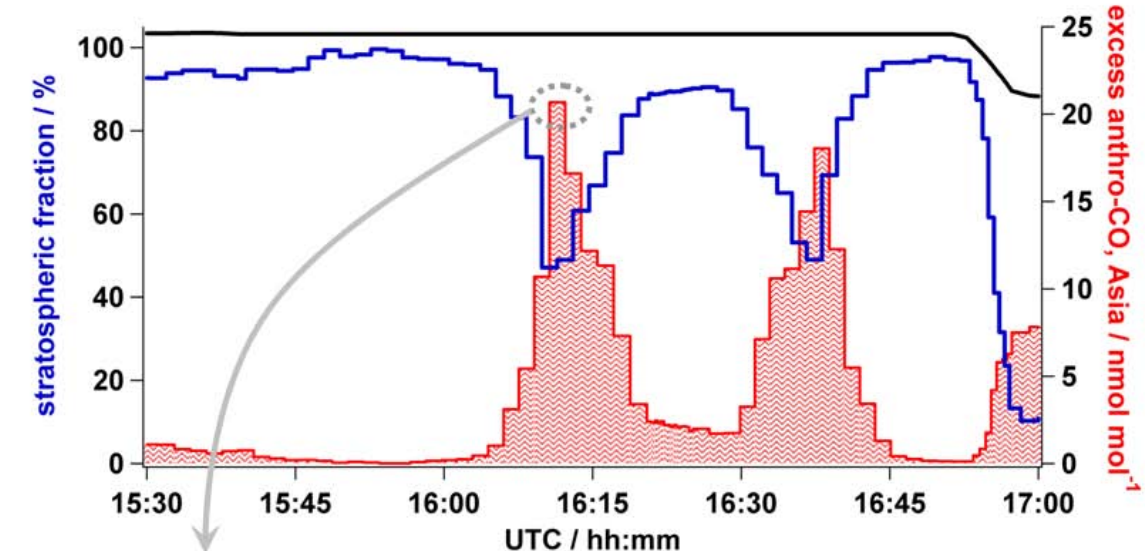

c)

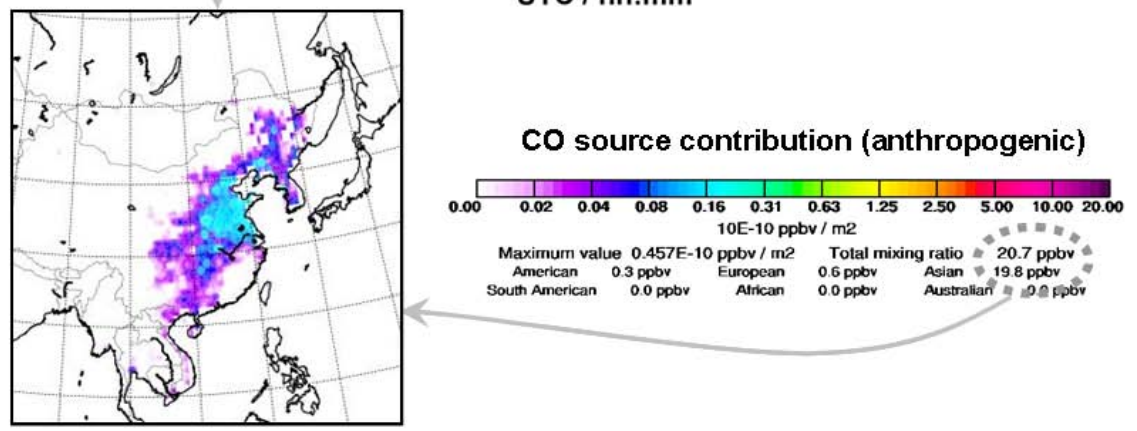

Fig. 3. (a) Time series of in-situ $\mathrm{CO}$ (red), $\mathrm{O}_{3}$ (blue), and pressure at flight altitude (black) for the same time period shown in Fig. 2. (b) Results of the FLEXPART backward analysis: the blue line gives the stratospheric fraction along the flight path. The red pattern represents the FLEXPART excess-CO originating from Asian anthropogenic pollution. (c) CO source contribution plot for 16:11 UTC (maximum $\mathrm{CO}$ concentration at $11.3 \mathrm{~km}$ altitude) with colour-scaling on the right.

temperature as a result of latent heat release. The strong uplift of the trajectories took place over eastern Russia between 5 July, 12:00 UTC ( $-126 \mathrm{~h})$ and 6 July, 18:00 UTC ( $-96 \mathrm{~h})$, as indicated by the grey dots in Fig. 4. According to FLEXPART, the pollution was emitted between $\sim 1-4$ July, i.e. $\sim 6-$ 10 days before our measurements. The polluted air mass was transported for a few days at low levels towards the northeast before it was exported from the boundary layer. The characteristics of strong and poleward ascent in combination with latent heat release suggests up-lift by a WCB, which is further investigated in the following section.

\subsection{Meteorological situation in the source region}

To study the ascent process within the warm conveyor belt, $48 \mathrm{~h}$ LAGRANTO forward trajectories were initiated on every grid point in a box over Asia $\left(90^{\circ} \mathrm{E}\right.$ to $150^{\circ} \mathrm{E}, 30^{\circ} \mathrm{N}$ to $75^{\circ} \mathrm{N}$ and between $1000 \mathrm{hPa}$ and $750 \mathrm{hPa}$ ), as indicated in Fig. 5. Within the 8-day period from 2 July 2008, 18:00 UTC to 10 July $2008,18: 00$ UTC, every $6 \mathrm{~h}$ a new set of trajectory calculations was initialised, and calculated for a $48 \mathrm{~h}$ interval. From all trajectories, only those showing a pressure decrease greater than $600 \mathrm{hPa}$ within $24 \mathrm{~h}$ were selected, and considered as warm conveyor belt trajectories. The computation of all selected $48 \mathrm{~h}$ WCB trajectories was then completed over 

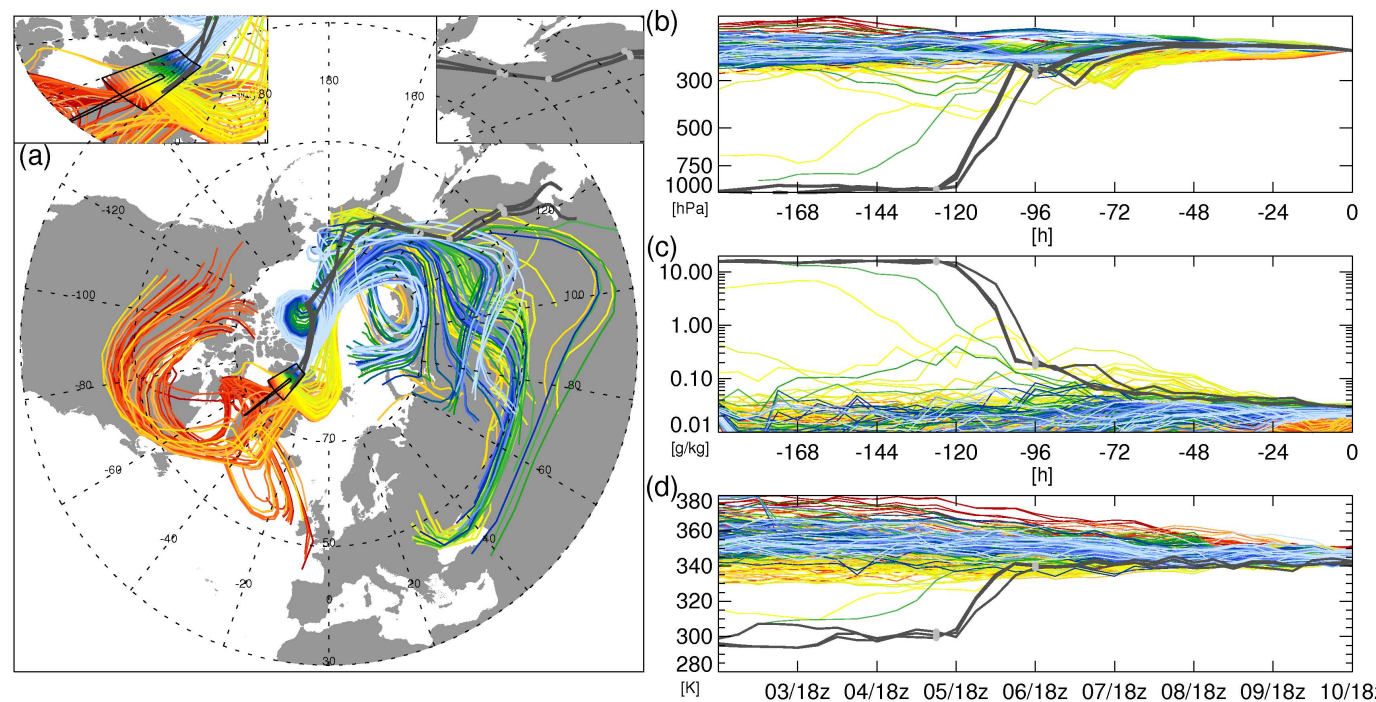

Fig. 4. LAGRANTO 8-day backward trajectories released on $10 \mathrm{July,} 18: 00 \mathrm{UTC}$, every $40 \mathrm{~km}$ inside the black box at $217 \mathrm{hPa}$. The box was centred around the encountered "MR". The flight track of the 10 July flight is shown as black line. The colour-code of the trajectories represents the starting latitude of the trajectories. Green trajectories belong approx. to the region of the "MR". Panel (a) gives a polar view of the pathways. Two sections are shown at a larger scale on the top: The release box (left) as well as the ascent over eastern Asia (right). The three panels (b), (c) and (d) show the evolution of pressure, specific humidity, and potential temperature along the trajectories. The time on the x-axis is relative to $10 \mathrm{July,} \mathrm{18:00} \mathrm{UTC.} \mathrm{The} \mathrm{trajectories} \mathrm{highlighted} \mathrm{as} \mathrm{thick} \mathrm{grey} \mathrm{lines} \mathrm{experience} \mathrm{a} \mathrm{strong} \mathrm{ascent} \mathrm{over} \mathrm{eastern} \mathrm{Asia.}$ Two time marks (gray dots) at $-126 \mathrm{~h}$ (5 July, 12:00 UTC) and at $-96 \mathrm{~h}$ (6 July, 18:00 UTC) indicate the location of this lifting process.

the entire 8-day period both by a forward and backward calculation. Figure 5 shows the position of the WCB parcels during the evolution of a cyclone with an embedded WCB. As the up-lift of the relevant air mass took place between 5 and 6 July (see Fig. 4), we only show WCB trajectories that ascended between 4 July, 00:00 UTC to 7 July, 18:00 UTC.

On 5 July, 00:00 UTC (Fig. 5a), the WCB parcels were located over the coastal regions of China and Korea as well as above the Yellow Sea, predominantly at altitudes below $900 \mathrm{hPa}$, and transported by south-westerly winds. The distribution matches partly the FLEXPART CO source contribution (Fig. 3c), with a shift towards the north-east due to the preceding low-level transport. Twelve hours later, the air mass was advected further north-eastward and a portion of the eastern parcels began rising when an upper level trough approached and caused cyclogenesis (Fig. 5b). At 6 July, 00:00 UTC a surface low developed and the parcels were situated close to the cyclone center and in the associated warm sector (Fig. 5c). North-east of the low, the parcels lined up along the warm front and reached the upper troposphere with pressure values up to $300 \mathrm{hPa}$. The parcels south of the surface low were located closer to the ground (Fig. 5d). Another $12 \mathrm{~h}$ later (6 July, 12:00 UTC) the surface low propagated further north eastward (Fig. 5e). Except for some parcels located at mid-levels $(500-800 \mathrm{hPa})$, the bulk reached the upper troposphere and was embedded in the jet stream located above the east coast of Asia. The majority of the WCB parcels were located in the diffluent exit region of the jet stream. Most parcels moved southward, however, those on the cyclonic side of the jet were embedded in the northeastward flow on the leading edge of a trough approaching from the north (see Fig. 5f). These parcels subsequently moved over the pole following the pathways illustrated in Fig. 4.

Of the 4296 selected WCB trajectories, a subset of 191 trajectories $(4.5 \%)$ was transported into the Arctic. The trajectories most likely to reach the Arctic were those located on the western side of the coherently ascending ensemble of trajectories. $92 \%$ of these Arctic WCB trajectories intersected the dynamical tropopause (PVU $>2$ ), compared to only $\sim 18 \%$ of the remaining WCB trajectories. Most parcels reached the $2 \mathrm{PVU}$ level right after the WCB ascent or when they were again lifted on the leading edge of the upper level trough. The latter ascent is also reflected in the pressure time series of Fig. 4 (see yellow and blue trajectories between -84 and $-72 \mathrm{~h}$ ). The trajectories travelling to Greenland show a further, continuous increase in PV during their journey, reaching values between 3 and 10 PVU by the time they arrive in our measurement area (not shown).

\subsection{Cross-polar transport and vertical structure of the polluted Asian air mass}

The transport of the Asian pollution plume across the pole is illustrated in Fig. 6. The left panel shows satellite image composites for 4 points in time, covering the time 

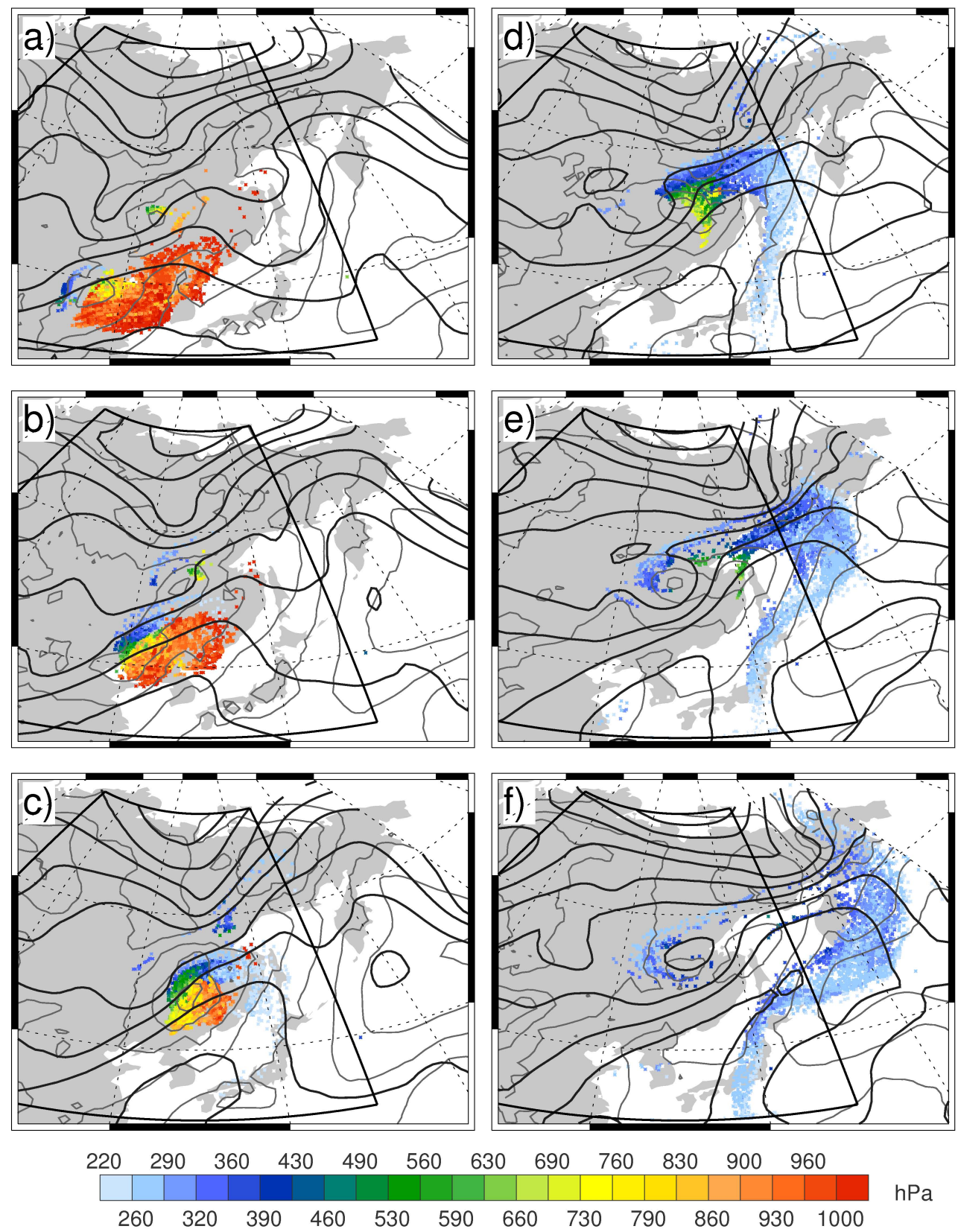

Fig. 5. Synoptic evolution from ECMWF analyses and position of WCB parcels at (a) 5 July, 00:00 UTC; (b) 5 July, 12:00 UTC; (c) 6 July, 00:00 UTC; (d) 6 July, 12:00 UTC, (e) 7 July, 00:00 UTC, and (f) 7 July, 12:00 UTC. Thick black lines show geopotential height at 300 hPa ( 80 gpm interval). Thin grey lines illustrate the mean sea level pressure ( $4 \mathrm{hPa}$ interval). The black polygon marks the region in which the trajectories were initialized (for details of the calculation method see Sect. 3.4). The colour-coded dots show location and pressure of the parcels at the respective time step.

period after the up-lift within the WCB (6 July 2008) to the day of our measurements above northern Greenland (10 July 2008). As described in Sect. 2.4, the cold upper-level cloud tops are illustrated by yellow and red colours. The white contour lines represent the FLEXPART Asian anthropogenic $\mathrm{CO}$ tracer, but only for the column above $9 \mathrm{~km}$. For the same points in time, the right panel shows maps of FLEXPART
Asian CO tracer plotted on $340 \mathrm{~K}$ isentropes. The red line indicates where the $325 \mathrm{~K}$ isentropes crosses the $2 \mathrm{PVU}$ surface, giving the approximate position of the jet stream. The red crosses indicate the location of a subset (every 8th) of the pole-crossing WCB forward trajectories (see Sect. 3.4). 


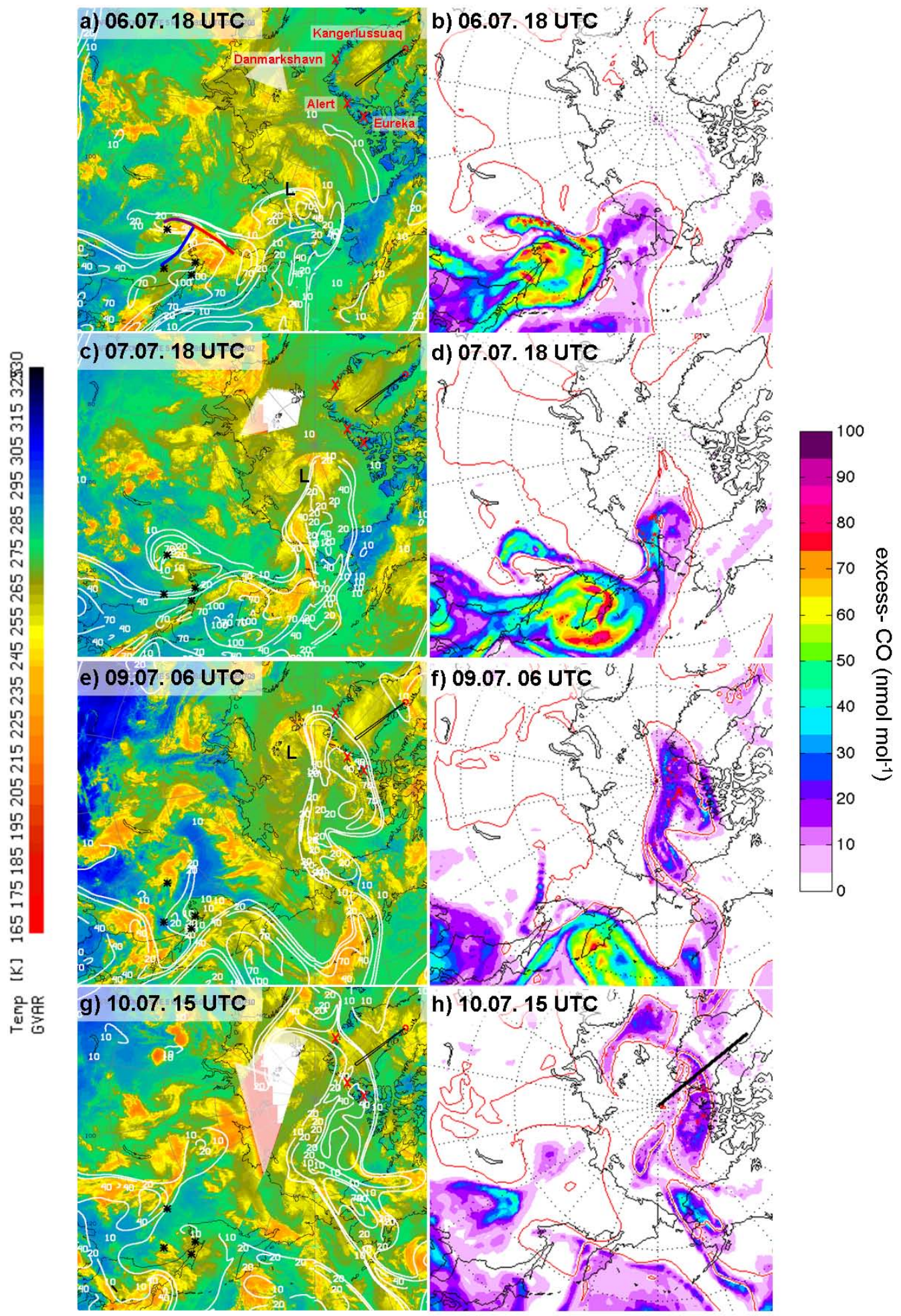

Fig. 6. Cross-polar transport of the Asian pollution. (a) and (b) 6 July, 18:00 UTC, (c) and (d) 7 July, 18:00 UTC, (e) and (f) 6 July, 09:00 UTC, (g) and (h) 10 July, 15:00 UTC. Left panels: Satellite composite images with colour-coded cloud top temperatures (see colourscaling at the left). White contour lines show FLEXPART Asian CO for the column above $9 \mathrm{~km}$. Black asterisks indicate locations of weather stations in the region of the WCB (marked by the fronts in panel (a)). The Falcon flight path is superimposed in panel (g). Right panels: FLEXPART Asian CO tracer plotted on the $340 \mathrm{~K}$ isentrope (see-colour-scaling on the right). Red line gives the location of the dynamical tropopause ( 2 PVU) at the $325 \mathrm{~K}$ surface. The red crosses indicate the position of the WCB forward trajectories. The black line shows the location of the cross section presented in Fig. 8. For more details see text. 
According to our trajectory analysis, the WCB ascent ahead of the cold front took place over Eastern Russia approximately between 5 July, 18:00 UTC and 7 July, 00:00 UTC. On 6 July, 18:00 UTC, our WCB trajectories reached the upper troposphere, coinciding with an area of enhanced CO tracer columns above $9 \mathrm{~km}$ of $100 \mathrm{~g} \mathrm{~m}^{-2}$ ahead of the cold front (Fig. 6a). Soundings from four weather stations (black asterisks in Fig. 6a) indicate that the minimum cloud top temperatures of $\sim 240-223 \mathrm{~K}$ within the WCB correspond to a maximum altitude of $\sim 11 \mathrm{~km}$. CO is used as a passive tracer with a life-time of 20 days in the FLEXPART model runs, therefore other CO pollution "remnants" north of Kamchatka/east of North Siberia are also visible in the upper troposphere, possibly from earlier lifting events. However, the polluted air mass lifted within the studied mid-latitude cyclone reached high potential temperatures of $340 \mathrm{~K}$, shown in a comparison with Fig. 6b. As indicated by the red line, a tropospheric streamer had already begun to intrude into the Arctic, ahead of an upper level trough. In the following hours and days, a low pressure system formed, deepened and moved further to the north (indicated with " $\mathrm{L}$ " in Fig. 6a, c, e). The polluted Asian air mass therefore was advected towards the North Pole (Fig. 6c, 7 July, 18:00 UTC). Whereas most of the Asian $\mathrm{CO}$ tracer was advected eastwards, some of the Asian $\mathrm{CO}$ was embedded in the streamer (Fig. 6d). A comparison of Fig. $6 \mathrm{c}$ and d shows that the region of enhanced FLEXPART tracer is accompanied partly by upper level clouds. During its journey, the polluted streamer was elongated and deformed (Fig. 6e and f, 9 July, 06:00 UTC). Finally, a portion of the polluted streamer reached northern Greenland, where it was sampled by the Falcon on 10 July (Fig. 6g and h, 10 July, 18:00 UTC). Figure 6h illustrates the good agreement with our in-situ data, showing that the polluted streamer was located almost perpendicular to our flight track, and was not completely traversed (see also Sect. 3.6).

During the cross-polar transport, the tropospheric streamer elevated the polar tropopause substantially (see also Fig. 1a). Figure 7 illustrates the temporal evolution of the vertical temperature structure during the advection of the streamer. Temperature profiles from soundings before, during and after the passage of the polluted streamer are presented exemplary for Eureka, Canada $\left(79.98^{\circ} \mathrm{N}, 85.95^{\circ} \mathrm{W}\right)$, and show a tropopause height variation of $\sim 2.5 \mathrm{~km}$. Due to the midlatitude origin of the polluted Asian air mass, the temperature at a fixed level in the middle to upper troposphere is $\sim 5$ to $10 \mathrm{~K}$ higher inside the Asian air mass (red solid lines) in comparison to the Arctic air mass (blue dotted lines), whereas the tropopause temperature is up to $\sim 7 \mathrm{~K}$ lower. The region above $\sim 13 \mathrm{~km}$ is less affected by the dynamics of the tropospheric streamer. During the passage of the Asian air mass the tropopause is sharper than before and after. The maximum thermal tropopause is $\sim 11.5 \mathrm{~km}$ (11 July, 00:00 UTC), which is slightly above our flight altitude $(11.3 \mathrm{~km})$. Note however the considerable temporal and spatial difference between the soundings and our in-situ measurements. An anal-

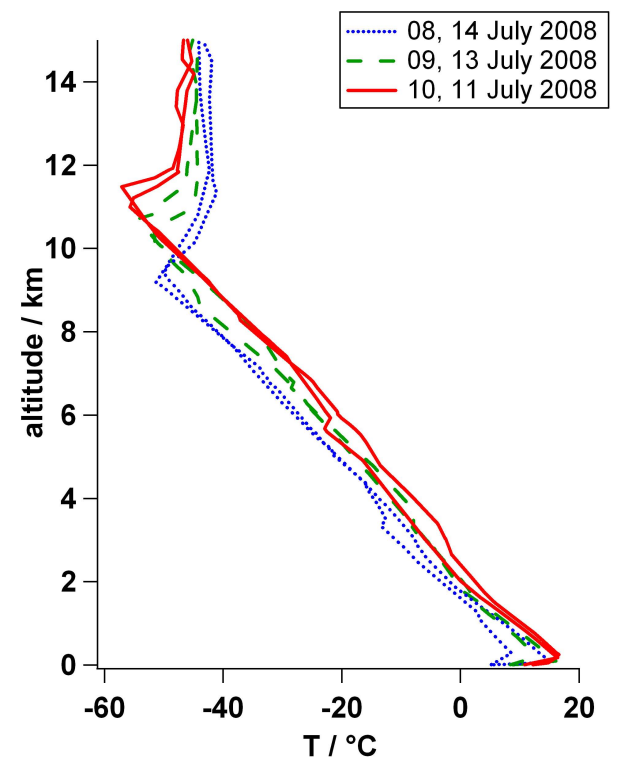

Fig. 7. Temperature profiles at Eureka, Canada $\left(79.98^{\circ} \mathrm{N}\right.$, $85.95^{\circ} \mathrm{W}$ ) as derived from radiosonde soundings on several days, each at 00:00 UTC (taken from http://weather.uwyo.edu/upperair/ sounding.html). The blue dotted lines represent profiles obtained before and after the polluted Asian air mass arrived at Eureka (8 July and 14 July 2008), respectively. The red solid lines show soundings during its passage (10 and 11 July 2008). The green dashed lines represent profiles from times between ( 9 and 13 July 2008).

ysis of ECMWF temperature profiles indicates that e.g. at the time of the observation, the thermal tropopause was $\sim 500 \mathrm{~m}$ lower in the sampled part of the streamer than above Eureka.

Figure 8 shows a vertical cross section of the FLEXPART Asian excess-CO tracer around the time of the flight (see black line in Fig. 6h). Also given are isentropes (black lines), the 2 PVU dynamical tropopause (thick black line), as obtained from the ECMWF analysis data, as well as isotaches (blue lines). The red crosses indicate the position of the WCB forward trajectories. Only WCB trajectory points located within $200 \mathrm{~km}$ of the Falcon flight path are shown (within $16: 30 \mathrm{~h} \pm 3 \mathrm{~h}$ ). Their abundance close to or above the 2 PVU tropopause reflects the strong selection criteria of the WCB forward analysis $(\triangle 600 \mathrm{hPa}$ within $24 \mathrm{~h})$.

According to the FLEXPART model simulation, the Falcon probed the topmost part of an Asian pollution plume with a vertical extension of several $\mathrm{km}$. The Asian excess-CO shows a maximum of $\sim 90$ to $100 \mathrm{nmol} \mathrm{mol}^{-1}$ at about $9 \mathrm{~km}$ just below the dynamic tropopause, at the edges of the tropospheric streamer. A part of the pollution reached the lowermost stratosphere, as indicated both by the 2 PVU tropopause and the closer spacing between the isentropes. According to ECMWF analysis, the plume was sampled $\sim 800 \mathrm{~m}$ above the dynamic tropopause and $\sim 400 \mathrm{~m}$ above the thermal tropopause, respectively. The Falcon nearly reached the centre of the streamer which is indicated by the region of the 


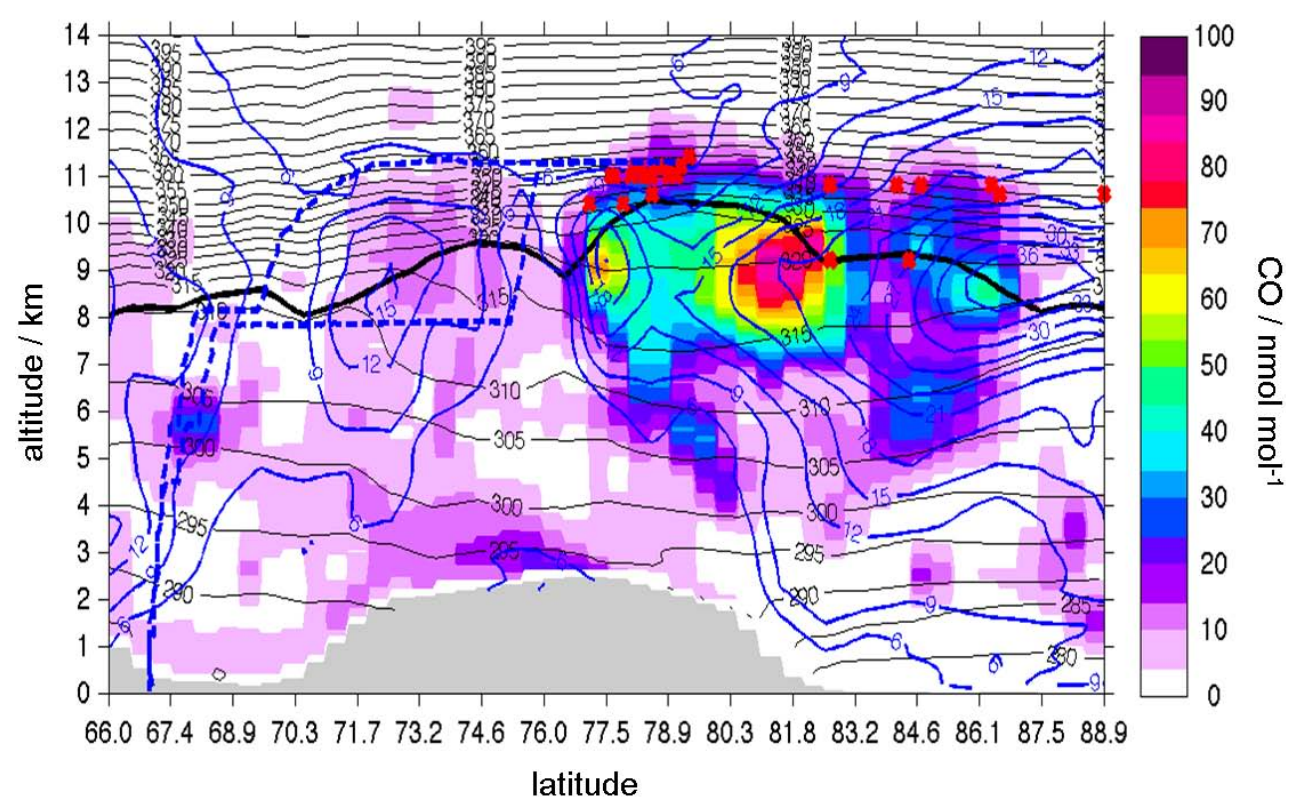

Fig. 8. Cross section of the FLEXPART Asian anthropogenic excess-CO tracer (see black line in Fig. 6h). Colours represent the modelled Asian excess-CO above atmospheric background values (see colour-scale on the right). The dashed blue line shows the Falcon flight path on 10 July. Also given are the 2 PVU dynamical tropopause (thick black line), isentropes (thin black lines), and isotaches (thin blue lines), as calculated from ECMWF analysis.

elevated dynamical tropopause. The Falcon probed the part of the streamer where the modelled excess- $\mathrm{CO}$ reached the highest altitude $(\sim 12.5 \mathrm{~km})$, with values of $\sim 20 \mathrm{nmol} \mathrm{mol}^{-1}$ at our flight level (see also Fig. 3b). The FLEXPART runs further indicate that the Asian air mass also contained emissions from Siberian forest fires, but only at altitudes between $\sim 4$ to $9 \mathrm{~km}$ and hence, below our flight level and below the 2 PVU tropopause (not shown).

\subsection{Discussion}

\subsubsection{Tracer-tracer correlations}

As shown in Sects. 3.2 and 3.3, both in-situ measurements and the FLEXPART analysis indicate that we probed an air mass of both stratospheric and tropospheric origin. In this section we discuss the chemical properties of the sampled air mass using correlations between different trace gases. Tracer-tracer relationships are a common tool to investigate mixing, chemical and/or transport processes in the tropopause region (Hoor et al., 2002, 2004; Pan et al., 2004, 2007; Kunz et al., 2009).

The red crosses in Fig. 9a-d represent the 10 July data observed inside the "MR". For comparison, the 10 July "LMS" data are also shown (black circles). The grey open circles represent all other GRACE data, as obtained from all 16 local flights. For the following discussion it is worth noting that although the GRACE measurement area was far from pollution sources, the sampled data do not represent summertime $\mathrm{CO}$ background values. In the free troposphere val- ues were biased towards higher $\mathrm{CO}$ mixing ratios (as well as PAN and $\mathrm{NO}_{\mathrm{y}}$ ). The Arctic mid-troposphere frequently was impacted by long-range transport of aged but CO-enriched pollution plumes, originating mainly in the boreal forest regions in Canada and Siberia (Singh et al., 2010; Schmale et al., 2011). Therefore, the median $\mathrm{CO}$ value between 4 to $9 \mathrm{~km}$ during GRACE was $\sim 140 \mathrm{nmol} \mathrm{mol}^{-1}$, whereas in the undisturbed troposphere of the northern mid- and high latitudes, $\mathrm{CO}$ mixing ratios typically range from approx. 80 to $120 \mathrm{nmol} \mathrm{mol}^{-1}$ (Emmons et al., 2000; Fischer et al., 2006).

Figure 9a shows an $\mathrm{O}_{3}-\mathrm{CO}$ scatter plot. $\mathrm{O}_{3}-\mathrm{CO}$ correlations help to diagnose STE (Stratosphere-TroposphereExchange) because both $\mathrm{O}_{3}$ and $\mathrm{CO}$ show distinct vertical gradients in the vicinity of the extratropical tropopause, with higher $\mathrm{O}_{3}$ in the stratosphere and higher $\mathrm{CO}$ in the troposphere, respectively. Ozone is mainly produced in the tropical stratosphere and has a life-time of approx. $1 \mathrm{yr}$ in the lowermost stratosphere (Solomon et al., 1985). In the troposphere, $\mathrm{O}_{3}$ values are highly variable due to in-situ photochemical production/destruction, dry deposition and import of stratospheric air. The main CO source in the background troposphere and the stratosphere is the oxidation of $\mathrm{CH}_{4}$. Other tropospheric $\mathrm{CO}$ sources are incomplete combustion processes from human activities or biomass burning, which makes $\mathrm{CO}$ an excellent pollution tracer. Its major sink is the reaction with $\mathrm{OH}$ radicals, which results in generally lower $\mathrm{CO}$ background values in the summer troposphere compared to winter, and for the same reason in the tropics compared to the middle and polar latitudes (Novelli et al., 1992, 2003). 

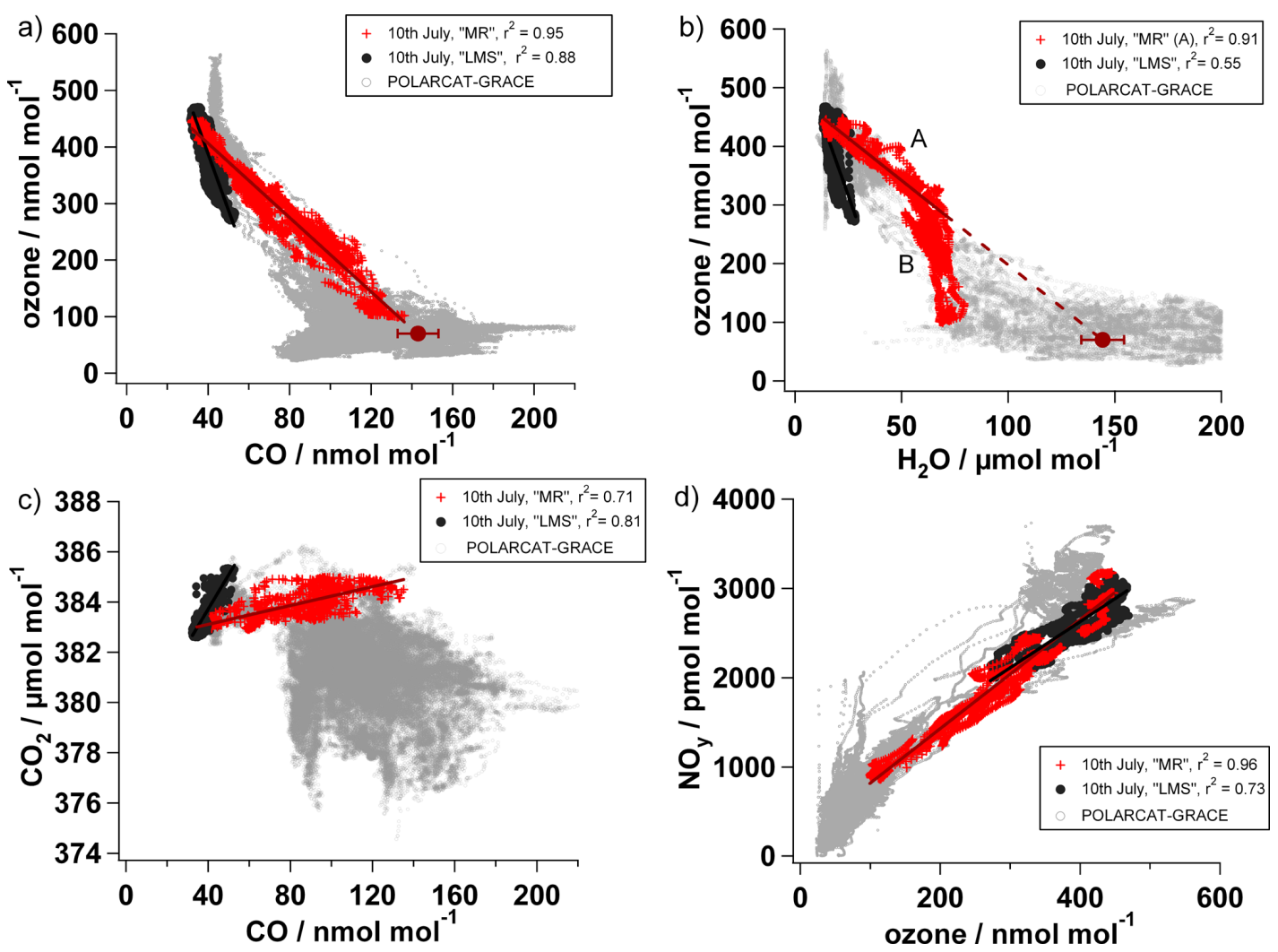

Fig. 9. Scatter plots of (a) $\mathrm{O}_{3}$ vs. $\mathrm{CO}$, (b) $\mathrm{O}_{3}$ vs. $\mathrm{H}_{2} \mathrm{O}$, (c) $\mathrm{CO}_{2}$ vs. $\mathrm{CO}$, and (d) $\mathrm{NO}_{\mathrm{y}}$ vs. $\mathrm{O}_{3}$. Data of the 10 July "MR" are shown as red crosses, the 10 July "LMS" data are given as black circles. Grey open circles represent all POLARCAT-GRACE measurements. See text for more details.

The "MR" data in the $\mathrm{O}_{3}$-CO scatter plot in Fig. 9a can be represented by a regression line, a so-called mixing line, which is formed by irreversible mixing of air parcels of both stratospheric and tropospheric origin. The slope of such a mixing line in a tracer-tracer space is dependent on the trace gas mixing ratios of the initial air masses (e.g. Hoor et al., 2002). The tropospheric character is found to be highest in the centre of the "MR" (see also Fig. 1b). Here, the $\mathrm{CO}$ mixing ratio of $\sim 138 \mathrm{nmol} \mathrm{mol}^{-1}$ suggests predominantly tropospheric origin whereas the ozone mixing ratio of $\sim 100 \mathrm{nmol} \mathrm{mol}^{-1}$ is already at the upper limit of typical tropospheric values. Although photochemical in-situ production in strongly polluted air masses may cause such high ozone values, this might indicate that also this part of the streamer had already mixed with ozone-rich stratospheric air masses. At the edges of the "MR", the entrainment of $\mathrm{O}_{3}$ rich, stratospheric air is more prominent.

A comparison of the "MR" data with the remaining GRACE data shows that the "MR" $\mathrm{CO}$ values in the tropopause region and above (i.e. $\mathrm{O}_{3}>100 \mathrm{nmol} \mathrm{mol}^{-1}$ ) are biased towards higher $\mathrm{CO}$ mixing ratios. This suggests that a $\mathrm{CO}$-enriched air mass was mixed into the lowermost stratosphere, which confirms the FLEXPART model results. If mixing and not chemical transformation is the dominant process, the extrapolation of the regression slope to an assigned tropospheric value of $\mathrm{O}_{3}$ gives an indication of the $\mathrm{CO}$ concentration of the "tropospheric end-member" (Hintsa et al., 1999; Hermann et al., 2000; Hoor et al., 2002). If we assume an upper tropospheric ozone mixing ratio of 70 $( \pm 30) \mathrm{nmol} \mathrm{mol}^{-1}$, we can calculate an initial CO mixing ratio of $143( \pm 10) \mathrm{nmol} \mathrm{mol}^{-1}$, as indicated by the dark red marker in Fig. 9a. It has to be pointed out that the tropospheric end-member represents only the tropospheric air mass just before it mixed with the stratospheric air. The WCB inflow regions however can be quite large (Wernli, 1997; Eckhardt et al., 2004), which means that the anthropogenic emissions certainly have been diluted with less polluted air already in the troposphere.

Figure $9 \mathrm{~b}$ shows the relation between $\mathrm{O}_{3}$ and $\mathrm{H}_{2} \mathrm{O}$. Water vapour mixing ratios show an even stronger gradient across the extratropical tropopause than $\mathrm{O}_{3}$ and $\mathrm{CO}$. The entry of $\mathrm{H}_{2} \mathrm{O}$ into the stratosphere occurs primarily in the tropics, however in the extratropics a moist mixing layer in the lowermost stratosphere is an indicator of troposphereto-stratosphere transport occurring at higher latitudes (e.g. Krebsbach et al., 2006). The moisture in the extratropical tropopause region is largely a function of the temperature at the cold point tropopause, but depends also on the relative 
strength of the different transport paths. Water vapour has a long chemical life-time in the tropopause region, but it is not conserved if condensation followed by precipitation occurs.

Apparently the "MR" data are divided into two regimes A and $\mathrm{B}$, which are separated approximately at $\mathrm{O}_{3}$ and $\mathrm{H}_{2} \mathrm{O}$ values of $280 \mathrm{nmol} \mathrm{mol}^{-1}$ and $65 \mu \mathrm{mol} \mathrm{mol}^{-1}$, respectively. The data in group A form a mixing line which can be extrapolated towards assigned tropospheric ozone values of 70 ( \pm 30$) \mathrm{nmol} \mathrm{mol}^{-1}$. The corresponding $\mathrm{H}_{2} \mathrm{O}$ end-member of $144( \pm 10) \mu \mathrm{mol} \mathrm{mol}^{-1}$ is indicated by the dark red marker in Fig. 9b. It gives an approximate value of the $\mathrm{H}_{2} \mathrm{O}$ content of the air mass after it was up-lifted within the WCB, but before it mixed with drier air from the stratosphere. This water vapour mixing ratio is in the same range of values obtained from the backward trajectory calculations, suggesting that after the strong loss of moisture that is characteristic of WCB lifting events, $\mathrm{H}_{2} \mathrm{O}$ mixing ratios of $\sim 0.06-0.1 \mathrm{~g} \mathrm{~kg}^{-1}$ (corresponding to $\sim 96-160 \mu \mathrm{mol} \mathrm{mol}^{-1}$ ) remain within the air mass (see grey trajectories in Fig. $4 \mathrm{c}$, at $-72 \mathrm{~h}$ ). The high water vapour mixing ratio in the WCB region raises the question whether this transport pathway may lead to an enhanced moistening of the extratropical lowermost stratosphere, though an upscaling cannot be done from our single event study. This might have implications for the temperature and chemistry of the UTLS, as water vapour plays an important role in the radiation budget and is a primary source of $\mathrm{HO}_{\mathrm{x}}$ radicals (e.g. Fueglistaler et al., 2009; Kunz et al., 2009). The data of group B correspond to the centre of the "MR", and clearly deviate from the regression line. Obviously water vapour was removed in this part of the air mass due to phase transition followed by sedimentation. This assumption is supported by the occurrence of the high-level clouds in some parts of the streamer, visible in the satellite images (e.g. Fig. 6c, e).

A $\mathrm{CO}_{2}-\mathrm{CO}$ scatter plot is presented in Fig. 9c. Apart from an increasing trend during the last decades due to industrialization, $\mathrm{CO}_{2}$ has seasonal, diurnal, and spatial variations. It is, for example, depleted during summertime in the lower troposphere by plant assimilation. This seasonal cycle, typically $\pm 1 \mu \mathrm{mol} \mathrm{mol}{ }^{-1}$ in the southern Hemisphere up to $\sim 15 \mu \mathrm{mol} \mathrm{mol}^{-1}$ in the northern boreal forest zone (Wigley and Schimel, 2000), is propagated into the lowermost stratosphere (e.g. Sawa et al., 2008; Boenisch et al., 2009). This is also reflected in the GRACE data, the observed $\mathrm{CO}_{2}$ mixing ratios were on average $\sim 2 \mu \mathrm{mol} \mathrm{mol}^{-1}$ lower in the troposphere than in the lowermost stratosphere: Median $\mathrm{CO}_{2}$ for $\mathrm{O}_{3}<100 \mathrm{nmol} \mathrm{mol}^{-1}$ was $381.4 \pm 0.4 \mu \mathrm{mol} \mathrm{mol}{ }^{-1}$ compared to $383.3 \pm 0.2 \mu \mathrm{mol} \mathrm{mol}^{-1}$ for $\mathrm{O}_{3}$ values $>100 \mathrm{nmol} \mathrm{mol}^{-1}$.

The "MR" data show a linear dependence between $\mathrm{CO}_{2}$ and $\mathrm{CO}$. Positive correlations between $\mathrm{CO}_{2}$ and $\mathrm{CO}$ are typically observed for combustion sources, and the $\triangle \mathrm{CO}_{2} / \triangle \mathrm{CO}$ enhancement ratio may provide information about the combustion efficiency. However, in this case the $\mathrm{CO}_{2} / \mathrm{CO}$ slope is driven by the mixing processes between the tropospheric and the stratospheric air masses. Due to the absence of well-defined (tropospheric) background values not affected by pollution, the enhancement ratio $\triangle \mathrm{CO}_{2} / \triangle \mathrm{CO}$ ratio is difficult to quantify. Nevertheless, the $\mathrm{CO}_{2} / \mathrm{CO}$ ratio of the air sample having the highest fraction of tropospheric air (i.e. $\mathrm{CO}_{2} \sim 385 \mu \mathrm{mol} \mathrm{mol}{ }^{-1}$ at $\mathrm{CO} \sim 140 \mathrm{nmol} \mathrm{mol}^{-1}$ ) clearly stands out from the remaining GRACE data, which were affected mainly by imported biomass burning plumes. This comparatively high $\mathrm{CO}_{2} / \mathrm{CO}$ ratio might be the combined result of two effects: Combustion efficiencies of industrial processes (e.g. of power plants) are much higher than those of forest fires, leading to initial $\mathrm{CO}_{2} / \mathrm{CO}$ slopes of up to a magnitude higher in anthropogenic plumes compared to biomass burning pollution (Andreae and Merlet, 2001; Suntharalingam et al., 2004). Additionally, the $\mathrm{CO}_{2}$ "background" might differ for these two different source regions. In densely populated areas like the North China Plain, respiratory $\mathrm{CO}_{2}$ of urban residents as well as agricultural soils and livestock is part of the anthropogenic plume and increases the $\mathrm{CO}_{2} / \mathrm{CO}$ ratio (Wang et al., 2010). On the contrary, $\mathrm{CO}_{2}$ plant uptake in boreal regions during summer leads to a decrease of this ratio.

Figure 9d shows a $\mathrm{NO}_{\mathrm{y}}-\mathrm{O}_{3}$ scatter plot. In the stratosphere, $\mathrm{NO}_{\mathrm{y}}$ is primarily composed of $\mathrm{HNO}_{3}$ and $\mathrm{NO}_{\mathrm{x}}$, produced mainly in the tropics by the photolysis of $\mathrm{N}_{2} \mathrm{O}$ followed by oxidation (Murphy et al., 1993). The $\mathrm{NO}_{\mathrm{y}}$ composition in the troposphere might differ considerably depending on sources/sinks, as well as region and altitude. As obvious in the GRACE data, correlations between $\mathrm{NO}_{\mathrm{y}}$ and $\mathrm{O}_{3}$ are typically steeper in the troposphere than in the stratosphere (Murphy et al., 1993). The $\mathrm{NO}_{\mathrm{y}}$ values of the "MR" data do not stand out from the remaining GRACE measurements, suggesting that although the air mass was influenced by anthropogenic pollution and hence, by emission of $\mathrm{NO}_{\mathrm{x}}$, the main part of the emitted $\mathrm{NO}_{\mathrm{y}}$ did not reach high altitudes. This is in agreement with earlier studies which show that the export of $\mathrm{NO}_{\mathrm{y}}$ from the boundary layer is not very efficient (Stohl et al., 2003; Koike et al., 2003; Nowak et al., 2004), mainly because of the removal of water-soluble $\mathrm{HNO}_{3}$ due to precipitation processes. Furthermore, the polluted air mass resided a few days in the boundary layer before it ascended within the WCB (see Sect. 3.3.2), which means that also dry deposition at the surface might have played a role.

Beyond $\mathrm{HNO}_{3}$, PAN is the most dominant $\mathrm{NO}_{\mathrm{y}}$ species found in aged pollution (Koike et al., 2003; Nowak et al., 2004; Singh et al., 2010). PAN is a product of hydrocarbon$\mathrm{NO}_{\mathrm{x}}$ chemistry and has long life-times in the mid- and upper troposphere (Talukdar et al., 1995). In the region of weakest stratospheric influence (i.e. at highest $\mathrm{CO}$ ), a maximum $\mathrm{PAN} / \mathrm{NO}_{\mathrm{y}}$ ratio of $\sim 0.3$ is observed. This ratio is rather low, $\mathrm{PAN} / \mathrm{NO}_{\mathrm{y}}$ ratios of up to $\sim 0.85$ have been measured in other CO plumes during GRACE, and ratios of e.g. $\sim 0.65$ in aged Asian pollution (Nowak et al., 2004). PAN is not affected by dry deposition and survives the up-lift in a mid-latitude cyclone (e.g. Miyazaki et al., 2003), but it has a life-time of only a few hours at the warm temperatures prevalent in the 
boundary layer (Talukdar et al., 1995). The low PAN content therefore is very likely the result of thermal decomposition during the low-level transport in the first days after emission. PAN may recycle back especially during night-time. However, in the humid boundary layer the released $\mathrm{NO}_{2}$ is efficiently oxidized to $\mathrm{HNO}_{3}$ (e.g. Bradshaw et al., 2000), especially during summer at these latitudes. As discussed earlier, most of the $\mathrm{HNO}_{3}$ in the WCB was presumably removed by wet deposition.

Compared to the "MR" slopes, the regression lines of the "LMS" data are much steeper for all correlations. The CO values of up to $50 \mathrm{nmol} \mathrm{mol}^{-1}$ are well above the stratospheric equilibrium value of 12 to $15 \mathrm{nmol} \mathrm{mol}^{-1}$ (Flocke et al., 1999) which suggests also for these air masses recent influence from the troposphere (e.g. Hoor et al., 2002, 2004; Tilmes et al., 2010), but to a lesser extent. Compared to the tropospheric air mass mixed into the "MR", the tropospheric air in the "LMS" case contained much less $\mathrm{H}_{2} \mathrm{O}$, PAN and $\mathrm{CO}$, but slightly higher $\mathrm{NO}_{\mathrm{y}}$ and much higher $\mathrm{CO}_{2}$.

\subsubsection{Mixing of Asian pollution with Arctic stratospheric air}

As discussed before, the polluted Asian air mass had already mixed with stratospheric air when it was sampled by the Falcon, although some interleaved filaments were still observed (see Sect. 3.2). An interesting question is of course, when and why did the tropospheric and stratospheric air masses mix? As mentioned in Sect. 3.4, most air parcels reached the 2 PVU level during the up-lift within the WCB, or later during the ascent at the leading edge of the upper level trough. Certainly mixing processes took place between the ascending Asian pollution and the lowermost stratospheric air located above, especially at the top of the lifted air mass.

However, we suggest that the main part of the troposphereto-stratosphere (TST) exchange evident in our data happened during the period of cross-polar transport at elevated levels: As mentioned in Sect. 3.5, the polar tropopause was vertically displaced during the passage of the tropospheric streamer. Temperature soundings from several weather stations (Eureka, Alert and Danmarkshavn, see red crosses in Fig. $6 \mathrm{~g}$ ) show an up-lift of the thermal tropopause of $\sim 2.5$ to $3 \mathrm{~km}$. This in turn implies that the polluted air mass was above $\sim 9$ to $10 \mathrm{~km}$ embedded by stratospheric air from the Arctic, while it was advected across the pole. As discussed in Sect. 3.5, the tropospheric streamer was elongated and stretched into long and narrow filaments during its journey. Therefore the most likely scenario is that horizontal shear induced turbulent mixing and thus, mass exchange across the air mass boundaries took place. As suggested by the "MR" in-situ data, $\mathrm{O}_{3}$-rich and CO-poor stratospheric air masses were entrained at the boundaries of the polluted filament. Another strong indication for more recent TST exchange is the linear mixing line which is observed in the $\mathrm{O}_{3}-\mathrm{CO}$ scatter plot (Fig. 9a). The quasi-ideal linear shape indicates mixing between two air masses having well-defined tracer "endmembers". Mixing processes at an earlier stage during the WCB uplift would rather be evident in deviations from this ideal mixing line (due to subsequent mixing and/or chemical processes). Finally, our assumption is also supported by the forward trajectory calculation started in the source region. As addressed in Sect. 3.4, the trajectories reach PV $>2$ PVU within the WCB ascent or shortly later. However, PV further increases along the forward trajectories travelling across the pole, finally reaching values between 3 and 10 PVU above Greenland. This additional gain in PV (and Theta) reflects, at least to some extent, further entrainment of PV-rich, warmer air from the stratosphere during the cross-polar transport.

However, we have to keep in mind that our data only represent a "snap-shot" in the temporal evolution of 3-dimensional mixing events, documenting the mixing stage only at one location and one point in time. The role of radiation (cooling/heating) is not discussed here, but may be relevant due to the existence of clouds, or at least humidity differences.

\section{Summary and conclusions}

During the research flight on 10 July 2008 an air mass containing unusually high $\mathrm{CO}, \mathrm{PAN}$, and $\mathrm{H}_{2} \mathrm{O}$ mixing ratios of $138 \mathrm{nmol} \mathrm{mol}^{-1}, 330 \mathrm{pmol} \mathrm{mol}^{-1}$ and $81 \mu \mathrm{mol} \mathrm{mol}^{-1}$ was sampled in the Arctic tropopause region at $11.3 \mathrm{~km}, \sim 800 \mathrm{~m}$ above the dynamical tropopause (2 PVU). In-situ tracer correlations and FLEXPART backward simulations show that we probed the topmost part of an air mass with recent tropospheric origin, containing anthropogenic pollution from East Asia mixed with $\mathrm{O}_{3}$-rich stratospheric air. As supported by a detailed trajectory analysis, the Asian pollution was uplifted within a WCB connected to a low pressure system over Northern Russia. The analysis also showed that $92 \%$ of the pole-crossing WCB trajectories reached the dynamical tropopause, mainly within the WCB ascent or shortly later. A part of the Asian pollution was embedded in a tropospheric streamer, which was advected across the pole. During its journey, the top of the polluted air mass was surrounded by Arctic stratospheric air. TST exchange most likely took place along the sides of the plume, when the tropospheric streamer was stretched into long and narrow filaments. Forward trajectory calculations initialized at the location of our observation show a steady increase in PV during the following 5 days (from 5.1 PVU to 9.4 PVU on average) suggesting that the pollution has been completely mixed into the lowermost stratosphere.

Correlation analyses show that the polluted tropospheric air mass was enriched mainly in $\mathrm{CO}, \mathrm{CO}_{2}$ and $\mathrm{H}_{2} \mathrm{O}$ before it was mixed into the stratosphere, whereas PAN and $\mathrm{NO}_{\mathrm{y}}$ have been efficiently removed before and during the up-lift within the WCB. While the wet removal of $\mathrm{HNO}_{3}$ is a regular occurrence in the transport pathway discussed herein, 
PAN generally has the potential to reach the tropopause region within WCB ascents, if the up-lift is not preceded by multi-day-transport in the warm boundary layer. The transport of pollution across the Pole was associated with an Arctic low-pressure system. Such cyclone events in the proximity of the North Pole are regular phenomena of the polar circulation, especially during summer (Serreze and Barret, 2007; Orsolini and Sorteberg, 2009), though the described cross-polar transport period was unusually strong (Sodemann et al., 2011).

Our study presents the first in-situ measurement of WCBlifted Asian pollution being stirred and finally irreversibly mixed into the polar lowermost stratosphere. In the context of our observations the question arises: is this transport process a common scenario that brings pollution to the polar lowermost stratosphere, as already suggested by climatological studies (Stohl, 2001; Wernli and Bourqui, 2002)? Our measurements are possibly linked to other observations: Dessler (2009) showed that even at high latitudes of 75$80^{\circ} \mathrm{N}$, cloud tops are found $\sim 20 \%$ of the time above the summertime tropopause. Since convection is not very frequent in these regions, WCBs may possibly be one reason for these observations. Furthermore, the lowermost stratosphere north of the jet stream contains a wide range of $\mathrm{CO}$ mixing ratios (Cooper et al., 2005), and in polar regions CO exceeds $100 \mathrm{nmol} \mathrm{mol}^{-1} 25 \%$ of the time in the $1 \mathrm{~km}$ thick layer above the summertime tropopause (Tilmes et al., 2010), indicating frequent entrainment of polluted air masses. The influence on local stratospheric chemistry is not clear: mixing of $\mathrm{O}_{3}$-rich stratospheric with $\mathrm{H}_{2} \mathrm{O}$-rich tropospheric air may results in enhanced $\mathrm{OH}$ mixing ratios and hence, a higher oxidation capacity (Esler et al., 2001). The influence of anthropogenic pollutants such as $\mathrm{CO}, \mathrm{CO}_{2}$, and $\mathrm{SO}_{2}$ however is difficult to predict.

Further research is required to (a) better assess the relevance of polluted WCBs on the Arctic UTLS region and (b) understand possible consequences on the chemical and radiative budget, especially in the context of rising Asian emissions and changing climate.

Acknowledgements. This work was supported by the Deutsche Forschungsgemeinschaft (DFG) under SPP 1294 (SCHL1857/2-1) and PAK 348 (SCHL1857/3-1). We thank the pilots, engineers and scientists from the DLR flight department for their excellent support during the campaign. Michael Lichtenstern and Paul Stock are greatly acknowledged for their help in acquiring this data set. We thank Gebhard Günther (FZ-Jülich) and Andreas Dörnbrack for helpful discussions. Harald Sodemann and Andreas Stohl were funded by the Norwegian Research Council in the framework of POLARCAT-Norway. K. S. Law was supported by the ANR/CNRS-INSU POLARCAT-France project. The Arctic composite images were produced from geostationary and polar orbiting satellite retrievals by the Space Science and Engineering Center, University of Wisconsin-Madison (funded by the Arctic Natural Science Program, Office of Polar Programs, National Science
Foundation Grant ARC-0713843). We acknowledge the University of Wyoming for providing sounding data to derive temperature profiles (http://weather.uwyo.edu/upperair/sounding.html).

Edited by: J. W. Bottenheim

\section{References}

Akimoto, H.: Global air quality and Pollution, Science, 302, 1716, doi:10.1126/science.1092666, 2003.

Andreae, M. and Merlet, P.: Emission of Trace Gases and Aerosols From Biomass Burning, Global Biogeochem. Cy., 15, 955-966, 2001.

Boering, K. A., Wofsy, S. C., Daube, B. C., Schneider, H. R., Loewenstein, M., Podolske, J. R., and Conway, T. J.: Stratospheric Mean Ages and Transport Rates from Observations of Carbon Dioxide and Nitrous Oxide, Science, 274, 1340-1343, doi:10.1126/science.274.5291.1340, 1997.

Bönisch, H., Engel, A., Curtius, J., Birner, Th., and Hoor, P.: Quantifying transport into the lowermost stratosphere using simultaneous in-situ measurements of $\mathrm{SF}_{6}$ and $\mathrm{CO}_{2}$, Atmos. Chem. Phys., 9, 5905-5919, doi:10.5194/acp-9-5905-2009, 2009.

Bradshaw, J., Davis, D., Grodzinsky, G., Smyth, S., Newell, R., Sandholm, S., and Liu, S.: Observed distributions of nitrogen oxides in the remote free troposphere from the NASA global tropospheric experiment programs, Rev. Geophys., 38, 61-116, 2000.

Brioude, J., Cooper, O. R., Trainer, M., Ryerson, T. B., Holloway, J. S., Baynard, T., Peischl, J., Warneke, C., Neuman, J. A., De Gouw, J., Stohl, A., Eckhardt, S., Frost, G. J., McKeen, S. A., Hsie, E.-Y., Fehsenfeld, F. C., and Nédélec, P.: Mixing between a stratospheric intrusion and a biomass burning plume, Atmos. Chem. Phys., 7, 4229-4235, doi:10.5194/acp-7-4229-2007, 2007.

Cooper, O. R., Moody, J. L., Parrish, D. D., Trainer, M., Ryerson, T. B., Holloway, J. S. Huebler, G., Fehsenfeld, F. C., and Evans, M. J.: Trace gas composition of midlatitude cyclones over the western North Atlantic Ocean: A conceptual model, J. Geophys. Res., 107, ACH-1-13, 2002.

Cooper, O. R., Forster, C., Parrish, D., Trainer, M., Dunlea, E., Ryerson, T., Hübler, G., Fehsenfeld, F., Nicks, D., Holloway, J., de Gouw, J., Warneke, C., Roberts, J. M., Flocke, F., and Moody, J.: A case study of transpacific warm conveyor belt transport: Influence of merging airstreams on trace gas import to North America, J. Geophys. Res., 109, D23S08, doi:10.1029/2003JD003624, 2004.

Cooper, O. R., Stohl, A., Hübler, G., Hsie, E. Y., Parrish, D. D., Tuck, A. F., Kiladis, E. N., Oltmans, S. J., Johnson, B. J., Shapiro, M., Moody, J. L., and Lefohn, A. S.: Direct transport of mid-latitude stratospheric ozone into the lower troposphere and marine boundary layer of the tropical Pacific Ocean, J. Geophys. Res., 110, D23310, doi:10.1029/2005JD005783, 2005.

Dessler, A. E.: Clouds and water vapour in the Northern hemisphere summertime stratosphere, J. Geophys. Res., 114, D00H09, doi:10.1029/2009JD012075, 2009.

Dickerson, R. R., Li, C., Li, Z., Marufu, L. T., Stehr, J. W., McClure, B., Krotkov, N., Chen, H., Wang, P., Xia, X., Ban, X., Gong, F., Yuan, J., and Yang, J.: Aircraft observations of dust and pollutants over northeast China: Insight into the meteorolog- 
ical mechanisms of transport, J. Geophys. Res., 112, D24S90, doi:10.1029/2007JD008999, 2007.

Ding, A., Wang, T., Xue, L., Gao, J., Stohl, A., Lei, H., Jin, D., Ren, Y., Wang, X., Wei, X., Qi, Y., Liu, J., and Zhang, X.: Transport of north China air pollution by mid-latitude cyclones: Case study of aircraft measurements in summer 2007, J. Geophys. Res., 114, D08304, doi:10.1029/2008JD011023, 2009.

Eckhardt, S., Stohl, A., Beirle, S., Spichtinger, N., James, P., Forster, C., Junker, C., Wagner, T., Platt, U., and Jennings, S. G.: The North Atlantic Oscillation controls air pollution transport to the Arctic, Atmos. Chem. Phys., 3, 1769-1778, doi:10.5194/acp3-1769-2003, 2003.

Eckhardt, S., Stohl, A., Wernli, H., James, P., Forster, C., and Spichtinger, N.: A 15-year Climatology of Warm Conveyor Belts, J. Climate, 17, 218-237, 2004.

Emmons, L. Hauglustaine, D., Müller, J. F., Carroll, M., Brasseur, G., Brunner, D., Staehelin, J., Thouret, V., and Marenco, A.: Data composites of airborne observations of tropospheric ozone and its precursors, J. Geophys. Res., 105(D16), 20497-20538, 2000.

Esler, J. G., Tan, D. G. H., Haynes, P. H., Evans, M. J., Law, K. S., Plantevin, P.-H., and Pyle, J. A.: Stratosphere-troposphere exchange: Chemical sensitivity to mixing, J. Geophys. Res., 106(D5), 4717-4731, 2001.

Esler, J. G., Haynes, P. H., Law, K. S., Barjat, H., Dewey, K., Kent, J., Schmitgen, S., and Brough, N.: Transport and mixing between airmasses in cold frontal regions during Dynamics and Chemistry of Frontal Zones (DCFZ), J. Geophys. Res., 108, 4142, doi:10.1029/2001JD001494, 2003.

Fiedler, V., Nau, R., Ludmann, S., Arnold, F., Schlager, H., and Stohl, A.: East Asian $\mathrm{SO}_{2}$ pollution plume over Europe - Part 1: Airborne trace gas measurements and source identification by particle dispersion model simulations, Atmos. Chem. Phys., 9, 4717-4728, doi:10.5194/acp-9-4717-2009, 2009.

Fischer, H., Wienhold, F. G., Hoor, P., Bujok, O., Schiller, C., Siegmund, P., Ambaum, M., Scheren, H. A., and Lelieveld, J.: Tracer correlations in the northern high-latitude lowermost stratosphere: Influence of cross-tropopause mass exchange, Geophys. Res. Lett., 27(1), 97-100, 2000.

Fischer, H., Lawrence, M., Gurk, Ch., Hoor, P., Lelieveld, J., Hegglin, M. I., Brunner, D., and Schiller, C.: Model simulations and aircraft measurements of vertical, seasonal and latitudinal $\mathrm{O}_{3}$ and CO distributions over Europe, Atmos. Chem. Phys., 6, 339-348, doi:10.5194/acp-6-339-2006, 2006.

Flocke, F., Herman, R. L., Salawitch, R. J., Atlas, E., Webster, C. R., Schauffler, S. M., Lueb, R. A., May, R. D., Moyer, E. J., Rosenlof, K. H., Scott, D. C., Blake, D. R., and Biu, T. P.: An examination of chemistry and transport processes in the tropical lower stratosphere using observations of long-lived and shortlived compounds obtained during STRAT and POLARIS, J. Geophys. Res., 104, 26625-26642, 1999.

Frost, G. J., McKeen, S. A., Trainer, M., Ryerson, T. B., Neuman, J. A., Roberts, J. M., Swanson, A., Holloway, J. S., Super, D. T., Fortin, T., Parrish, D. D., Fehsenfeld, F. C., Flocke, F., Peckham, S. E., Grell, G. A., Kowal, D., Cartwright, J., Auerbach, N., and Habermann, T.: Effects of changing power plant $\mathrm{NO}_{\mathrm{x}}$ emissions on ozone in the eastern United States: Proof of concept, J. Geophys Res., 111, D12306, doi:10.1029/2005JD006354, 2006.
Fueglistaler, S., Dessler, A. E., Dunkerton, T. J., Folkins, I., Fu, Q., and Mote, P. W: Tropical tropopause layer, Rev. Geophys., 47, RG1004, doi:10.1029/2008RG000267, 2009.

Gerbig, C., Schmitgen, S., Kley, D., Volz-Thomas, A., Dewey, K., and Haaks, D.: An improved fast-response vacuum-UV resonance fluorescence CO instrument, J. Geophys. Res., 104, 16991704, 1999.

Herman, R. L., Webster, C. R., May, R. D., Scott, D. C., Hu, H., Moyer, E. J., Wennberg, P. O., Hanisco, T. F., Lanzendorf, E. J., Salawitch, R. J., Yung, Y. L., Margitan, J. J., and Bui, T. P.: Measurements of $\mathrm{CO}$ in the upper troposphere and lowermost stratosphere, Chemos.-Global Change Sci., 1, 173-183, 1999.

Hintsa, E. J., Boering, K. A., Weinstock, E. M., Anderson, J. G., Gary, B. L., Pfister, L., Daube, B. C., Wofsy, S. C., Loewenstein, M., Podolske, J. R., Margitan, J. J., and Biu, T. P.: Troposphere to stratosphere transport in the lowermost stratosphere from measurements of $\mathrm{H}_{2} \mathrm{O}, \mathrm{CO}_{2}, \mathrm{~N}_{2} \mathrm{O}$ and $\mathrm{O}_{3}$, Geophys. Res. Lett., 25, 2655-2658, 1999.

Holton, J. R., Haynes, P. H., McIntyre, M. E., Douglass, A. R., Rood, R. B., and Pfister, L.: Stratosphere-Troposphere Exchange, Rev. Geophys., 33, 403-439, 1995.

Hoor, P., Fischer, H., Lange, L., Lelieveld, J., and Brunner, D.: Seasonal variations of a mixing layer in the lowermost stratosphere as identified by the $\mathrm{CO}-\mathrm{O}_{3}$ correlation from in-situ measurements, J. Geophys. Res., 107, ACL 1-1-18, 2002.

Hoor, P., Gurk, C., Brunner, D., Hegglin, M. I., Wernli, H., and Fischer, H.: Seasonality and extent of extratropical TST derived from in-situ CO measurements during SPURT, Atmos. Chem. Phys., 4, 1427-1442, doi:10.5194/acp-4-1427-2004, 2004.

Hudman, R. C.: Ozone production in transpacific Asian pollution plumes and implications for ozone air quality in California, J. Geophys. Res., 109, D23S10, doi:10.1029/2004JD004974, 2004.

Jacob, D. J., Crawford, J. H., Kleb, M. M., Connors, V. S., Bendura, R. J., Raper, J. L., Sachse, G. W., Gille, J. C., Emmons, L., and Heald, C. L.: Transport and Chemical Evolution over the Pacific (TRACE-P) aircraft mission: Design, execution, and first results, J. Geophys. Res., 108, 9000, doi:10.1029/2002JD003276, 2003.

Jaffe, D., Anderson, T., Covert, D., Kotchenruther, R., Trost, B., Danielsen, J., Simpson, W., Berntsen, T., Karlsdottir, S., Blake, D., Harris, J., Carmichael, G., and Uno, I.: Transport of Asian air pollution to North America, Geophys. Res. Lett., 26, 711714, 1999.

Jaffe, D., McKendry, I., Anderson, T., and Price, H.: Six 'new' episodes of trans-Pacific transport of air pollutants, Atmos. Environ., 37, 391-404, 2003.

Jaeglé, L., Jaffe, D. A., Price, H. U., Weiss-Penzias, P., Palmer, P. I., Evans, M. J., Jacob, D. J., and Bey, I.: Sources and budgets for $\mathrm{CO}$ and $\mathrm{O}_{3}$ in the northeastern Pacific during the spring of 2001: Results from the PHOBEA-II Experiment, J. Geophys. Res., 108, 8802, doi:10.1029/2002JD003121, 2003.

Koike, M., Kondo, Y., Kita, K., Takegawa, N., Masui, Y., Miyazaki, Y., Ko, M. W., Weinheimer, A. J., Flocke, F., Weber, R. J., Thornton, D. C., Sachse, G. W., Vay, S. A., and Blake, D. R.: Export of anthropogenic reactive nitrogen and sulfur compounds from the East Asia region during spring, J. Geophys. Res., 108, GTE 10-1-19, doi:10.1029/2002JD003284, 2003.

Krebsbach, M., Schiller, C., Brunner, D., Günther, G., Hegglin, M. I., Mottaghy, D., Riese, M., Spelten, N., and Wernli, H.: Sea- 
sonal cycles and variability of $\mathrm{O}_{3}$ and $\mathrm{H}_{2} \mathrm{O}$ in the UT/LMS during SPURT, Atmos. Chem. Phys., 6, 109-125, doi:10.5194/acp6-109-2006, 2006.

Kunz, A., Konopka, P., Müller, R., Pan, L. L., and Rohrer, F.: High static stability in the mixing layer above the extratropical tropopause, J. Geophys. Res., 114, D16305, doi:10.1029/2009JD011840, 2009.

Law, K. and Stohl, A.: Arctic Air Pollution: Origins and Impact, Science, 16, 1537-1540, doi:10.1126/science.1137695, 2007.

Lazzara, M. A. and Knuth, S. L.: Arctic and Antarctic Satellite composite Imagery, Polar Science, in preparation, 2011.

Lazzara, M. A., Coletti, A., and Diedrich, B. L.: The possibilities of polar meteorology, environmental remote sensing, communications and space weather applications from artificial Lagrange orbit, Adv. Space Res., accepted, 2011.

Liang, Q., Rodriguez, J. M., Douglass, A. R., Crawford, J. H., Apel, E., Bian, H., Blake, D. R., Brune, W., Chin, M., Colarco, P. R., da Silva, A., Diskin, G. S., Duncan, B. N., Huey, L. G., Knapp, D. J., Montzka, D. D., Nielsen, J. E., Olson, J. R., Pawson, S., Weinheimer, A. J., and Reimer, D. D.: Reactive nitrogen, ozone and ozone production in the Arctic troposphere and the impact of stratosphere-troposphere exchange, Atmos. Chem. Phys. Discuss., 11, 10721-10767, doi:10.5194/acpd-11-107212011, 2011.

Mari, C., Evans, M. J., Palmer, P. I., Jacob, D. J., and Sachse, G. W.: Export of Asian pollution during two cold front episodes of the TRACE-P experiment, J. Geophys. Res., 109, D15S17, doi:10.1029/2003JD004307, 2004.

Miyazaki, Y., Kondo, Y., Koike, M., Fuelberg, H. E., Kiley, C. M., Kita, K., Takeqawa, N., Sachse, G. W., Flocke, F., Weinheimer, A. J., Singh, H. B., Eisele, F. L., Zondlo, M., Talbot, R. W., Sandholm, S.T., Avery, M. A., and Blake, D. R.: Synoptic-scale transport of reactive nitrogen over the western Pacific in spring, J. Geophys. Res., 108, 8788, doi:10.1029/2002JD003248, 2003.

Murphy, D., Fahey, D., Proffitt, M., Liu, S., Chan, K., Eubank, C., Kawa, S., and Kelly, K.: Reactive Nitrogen and Its Correlation With Ozone in the Lower Stratosphere and Upper Troposphere, J. Geophys. Res., 98, 8751-8773, 1993.

Neuman, J. A., Parrish, D. D., Ryerson, T. B., Brock, C. A., Wiedinmyer, C., Frost, G. J., Holloway, J. S., and Fehsenfeld, F. C.: Relationship between photochemical ozone production and $\mathrm{NO}_{\mathrm{x}}$ oxidation in Houston, Texas, J. Geophys. Res., 114, D00F08, doi:10.1029/2004JD005092, 2009.

Novelli, P. C., Steele, L. P., and Tans, P. P.: Mixing ratios of Carbon Monoxide in the Troposphere, J. Geophys. Res., 97, 2073120750, 1992.

Novelli, P. C., Masarie, K. A., Lang, P. M., Hall, B. D., Myers, R. C., and Elkins, J. W: Reanalysis of tropospheric CO trends: Effects of the 1997-1998 Wildfires, J. Geophys. Res., 108, doi:10.1029/2002JD003031, 2003.

Nowak, J., Parris, D. D., Neuman, J. A., Holloway, J. S., Cooper. O. R., Ryerson, T. B., Nicks, D. K., Flocke, F., Roberts, J. M., Atlas, E., de Gouw, J. A., Donnelly, S., Dunlea, E., Hübler, G., Huey, L. G., Schauffler, S., Tanner, D. J., Warneke, C., and Fehsenfeld, F. C. S.: Gas-phase chemical characteristics of Asian emission plumes observed during ITCT 2K2 over the eastern North Pacific Ocean, J. Geophys. Res., 109, D23S19, doi:10.1029/2003JD004488, 2004.
Orsolini, Y. J. and Sorteberg, A.: Projected changes in Eurasian and Arctic summer cyclones under global warming in the Bergen Climate Model, Atmos. Oceanic Sci. Lett., 2, 62-67, 2009.

Pan, L. L., Randel, W. J., Gary, B. L., Mahoney, M. J., and Hinsta, E. J.: Definitions and sharpness of the extratropical tropopause: A trace gas perspective, J. Geophys. Res., 109, D23103, doi:10.1029/2004JD004982, 2004.

Pan, L. L., Konopka, P., and Browell, E. V.: Observations and model simulations of mixing near the extratropical tropopause, J. Geophys. Res., 111, D05106, doi:10.1029/2005JD006480, 2006.

Pan, L. L., Bowman, K. P., Shapiro, M., Randel, W. J., Gao, R. S., Campos, T., Davis, C., Schauffler, S., Ridley, B. A., Wei, J. C., and Barbet, C.: Chemical behaviour of the tropopause observed during the Stratosphere-Tropophere Analyses of Regional Transport Experiment, J. Geophys. Res., 112, D18110, doi:10.1029/2007JD008645, 2007.

Paris, J. D., Stohl, A., Ndlec, P., Arshinov, M. Yu., Panchenko, M. V., Shmargunov, V. P., Law, K. S., Belan, B. D., and Ciais, P.: Wildfire smoke in the Siberian Arctic in summer: source characterization and plume evolution from airborne measurements, Atmos. Chem. Phys., 9, 9315-9327, doi:10.5194/acp-9-9315-2009, 2009.

Parrish, D., Holloway, J., Jakoubek, R., Trainer, M., Ryerson, T., Hübler, G., Fehsenfeld, F., Moody, J., and Cooper, O.: Mixing of anthropogenic pollution with stratospheric ozone: A case study from the North Atlantic wintertime troposphere, J. Geophys. Res., 105, 24363-24374, 2000.

Plumb, R. A. and Ko, M. K. W.: Interrelationships between mixing ratios of long-lived stratospheric constituents, J. Geophys. Res., 97, 10145-10156, 1992.

Reed, R. J. and Kunkel, B. A.: The Arctic circulation in summer, J. Atmos. Sci., 17, 489-506, 1960.

Richter, A., Burrows, J. P., Nueß, H., Granier, C., and Niemeier, U.: Increase in tropospheric nitrogen dioxide over China observed from space, Lett. Nature, 437, doi:10.1038/nature04092, 2005.

Roiger, A., Aufmhoff, H., Stock, P., Arnold, F., and Schlager, H.: An aircraft-borne chemical ionization - ion trap mass spectrometer (CI-ITMS) for fast PAN and PPN measurements, Atmos. Meas. Tech., 4, 173-188, doi:10.5194/amt-4-173-2011, 2011.

Sawa, Y., Machida, T., and Matsueda, H.: Seasonal variations of $\mathrm{CO}_{2}$ near the tropopause observed by commercial aircraft, J. Geophys. Res., 113, D23301, doi:10.1029/2008JD010568, 2008.

Schmale, J., Schneider, J., Ancellet, G., Quennehen, B., Stohl, A., Sodemann, H., Burkhart, J., Hamburger, T., Arnold, S. R., Schwarzenboeck, A., Borrmann, S., and Law, K. S.: Source identification and airborne chemical characterisation of aerosol pollution from long-range transport over Greenland during POLARCAT summer campaign 2008, Atmos. Chem. Phys., 11, 1009710123, doi:10.5194/acp-11-10097-2011, 2011.

Serreze, M. C. and Barrett, A. P.: The summer cyclone maximum over the central Arctic ocean, J. Climate, 21, 1048-1065, 2008.

Shindell, D. T., Chin, M., Dentener, F., Doherty, R. M., Faluvegi, G., Fiore, A. M., Hess, P., Koch, D. M., MacKenzie, I. A., Sanderson, M. G., Schultz, M. G., Schulz, M., Stevenson, D. S., Teich, H., Textor, C., Wild, O., Bergmann, D. J., Bey, I., Bian, H., Cuvelier, C., Duncan, B. N., Folberth, G., Horowitz, L. W., Jonson, J., Kaminski, J. W., Marmer, E., Park, R., Pringle, K. J., Schroeder, S., Szopa, S., Takemura, T., Zeng, G., Keating, T. J., and Zuber, A.: A multi-model assessment of pollu- 
tion transport to the Arctic, Atmos. Chem. Phys., 8, 5353-5372, doi:10.5194/acp-8-5353-2008, 2008.

Singh, H. B., Brune, W. H., Crawford, J. H., Flocke, F., and Jacob, D. J.: Chemistry and transport of pollution over the Gulf of Mexico and the Pacific: spring 2006 INTEX-B campaign overview and first results, Atmos. Chem. Phys., 9, 2301-2318, doi:10.5194/acp-9-2301-2009, 2009.

Singh, H. B., Anderson, B. E., Brune, W. H., Cai, C., Cohen, R. C., Crawford, J. H., Cubison, M. J., Czech, E. P., Emmons, L., Fuelberg, H. E., Huey, G., Jacob, D. J., Jimenez, J. L., Kaduwela, A., Kondo, Y., Mao, J., Olson, R. J., Sachse, G. W., Vay, S. A., Weinheimer, A., Wennberg, P. O., Wisthaler, A., and the ARCTAS Science Team: Pollution influences on atmospheric composition and chemistry at high northern latitudes, Boreal and California forest fire emissions, Atmos. Environ., 44, 4553-4564, 2010.

Sodemann, H., Pommier, M., Arnold, S. R., Monks, S. A., Stebel, K., Burkhart, J. F., Hair, J. W., Diskin, G. S., Clerbaux, C., Coheur, P.-F., Hurtmans, D., Schlager, H., Blechschmidt, A.-M., Kristjánsson, J. E., and Stohl, A.: Episodes of cross-polar transport in the Arctic troposphere during July 2008 as seen from models, satellite, and aircraft observations, Atmos. Chem. Phys., 11, 3631-3651, doi:10.5194/acp-11-3631-2011, 2011.

Solomon, S., Garcia, R., and Stordal, F.: Transport Processes and Ozone Perturbations, J. Geophys. Res., 90, 12981-12989, 1985.

Stohl, A.: A one-year Lagrangian "climatology" of airstreams in the northern hemisphere troposphere and lowermost stratosphere, J. Geophys. Res., 106, 7263-7279, 2001.

Stohl, A.: Characteristics of atmospheric transport into the Arctic troposphere, J. Geophys. Res., 111, D11306, doi:10.1029/2005JD006888, 2006.

Stohl, A. and Thomson, D. J.: A density correction for Lagrangian particle dispersion models, Bound.-Lay. Meteorol., 90, 155-167, 1999.

Stohl, A. and Trickl, T.: A textbook example of long-range transport: Simultaneous observation of ozone maxima of stratospheric and North American origin in the free troposphere over Europe, J. Geophys. Res., 104, 30445-30462, 1999.

Stohl, A., Trainer, M., Ryerson, T. B., Holloway, J. S., and Parrish, D. D.: Export of $\mathrm{NO}_{\mathrm{y}}$ from the North American boundary layer during 1996 and 1997 North Atlantic Regional Experiments, J. Geophys. Res., 107, doi:10.1029/2001JD000519, 2002.

Stohl, A., Forster, C., Eckhardt, S., Spichtinger, N., Huntrieser, H., Heland, J., Schlager, H., Wilhelm, S., Arnold, F., and Cooper, O.: A backward modeling study of intercontinental pollution transport using aircraft measurements, J. Geophys. Res., 108, 4370, doi:10.1029/2002JD002862, 2003.

Stohl, A., Forster, C., Frank, A., Seibert, P., and Wotawa, G.: Technical note: The Lagrangian particle dispersion model FLEXPART version 6.2, Atmos. Chem. Phys., 5, 2461-2474, doi:10.5194/acp-5-2461-2005, 2005.

Stohl, A., Forster, C., Huntrieser, H., Mannstein, H., McMillan, W. W., Petzold, A., Schlager, H., and Weinzierl, B.: Aircraft measurements over Europe of an air pollution plume from Southeast Asia - aerosol and chemical characterization, Atmos. Chem. Phys., 7, 913-937, doi:10.5194/acp-7-913-2007, 2007.

Suntharalingam, P., Jacob, D. J., Palmer, P. I., Logan, J. A., Yantosca, Y. M., Xiao, Y., Evans, M., Streets, D. G., Vay, S. L., and Sachse, G. W.: Improved quantification of Chinese carbon fluxes using $\mathrm{CO}_{2} / \mathrm{CO}$ correlations in Asian outflow, J. Geophys. Res.,
109, D18S18, doi:10.1029/2003JD004362, 2004.

Talukdar, R. K., Burkholder, J. B., Schmoltner, A.-M., Roberts, J. M., Wilson, R. R., and Ravishankara, A. R.: Investigation of the loss processes for peroxyacetyl nitrate in the atmosphere: UV photolysis and reaction with OH, J. Geophys. Res., 100, $14163-$ 14173, 1995.

Tilmes, S., Pan, L. L., Hoor, P., Atlas, E., Avery, M. A., Campos, T., Christensen, L. E., Diskin, G. S., Gao, R. S., Herman, R. L., Hintsa, E. J., Loewenstein, M., Lopez, J., Paige, M. E., Pittman, J. V., Podolske, J. R., Proffitt, M. R., Sachse, G. W., Schiller, C., Schlager, H., Smith, J., Spelten, N., Webster, C., Weinheimer, A., and Zondlo, M. A.: An aircraft-based upper troposphere lower stratosphere $\mathrm{O}_{3}, \mathrm{CO}$ and $\mathrm{H}_{2} \mathrm{O}$ climatology for the Northern Hemisphere, J. Geophys. Res., 115, D14303, doi:10.1029/2009JD012731, 2010.

Trickl, T., Cooper, O. R., Eisele, H., James, P., Mücke, R., and Stohl, A.: Intercontinental transport and its influence on the ozone concentrations over central Europe: Three case studies, J. Geophys. Res., 108, 8530, doi:10.1029/2002JD002735, 2003.

Wang, Y., Munger, J. W., Xu, S., McElroy, M. B., Hao, J., Nielsen, C. P., and Ma, H.: $\mathrm{CO}_{2}$ and its correlation with $\mathrm{CO}$ at a rural site near Beijing: implications for combustion efficiency in China, Atmos. Chem. Phys., 10, 8881-8897, doi:10.5194/acp-10-88812010, 2010.

Wernli, H. and Bourqui, M.: A Lagrangian "1-year climatology" of (deep) cross-tropopause exchange in the extratropical northern hemisphere, J. Geophys. Res., 107, ACL 13-1-13-16, 2002.

Wernli, H. and Davies, H. C.: A Lagrangian-based analysis of extratropical cyclones. I: The method and some applications, Quart. J. Roy. Meteorol. Soc., 123, 467-489, 1997.

Wernli, H.: A Lagrangian-based analysis of extratropical cyclones. II: A detailed case study. Quart. J. Roy. Meteorol. Soc., 123, 1677-1706, 1997.

Wigley, T. M. L. and Schimel, D. S.: The carbon cycle, Cambridge University Press, Cambridge, 7-36, 2000.

Wild, O. and Akimoto, H.: Intercontinental transport of ozone and its precursors in a three-dimensional global CTM, J. Geophys. Res., 106, 27729-27744, 2001.

Wooster and Zhang: Boreal forest fires burn less intensely in Russia than in North America, Geophys. Res. Lett., 31, L20505, doi:10.1029/2004GL020805, 2004.

Zahn, A. and Brenninkmeijer, C.: New directions: A chemical tropopause defined, Atmos. Environ., 37, 439-440, 2003.

Zahn, A., Brenninkmeijer, C. A. M., Maiss, M., Scharffe, D. H., Crutzen, P. J., Herrmann, M., Heintzenberg, J., Wiedensohler, A., Güsten, H., Heinrich, G., Fischer, H., Cuijpers, J. W. M., and van Velthofen, P. F. J.: Identification of extratropical tropospherestratosphere mixing based on CARIBIC measurements of $\mathrm{O}_{3}$, $\mathrm{CO}$ and ultra-fine particles, J. Geophys. Res., 105, 1527-1535, 2000.

Zhang, Q., Streets, D. G., Carmichael, G. R., He, K. B., Huo, H., Kannari, A., Klimont, Z., Park, I. S., Reddy, S., Fu, J. S., Chen, D., Duan, L., Lei, Y., Wang, L. T., and Yao, Z. L.: Asian emissions in 2006 for the NASA INTEX-B mission, Atmos. Chem. Phys., 9, 5131-5153, doi:10.5194/acp-9-5131-2009, 2009.

Ziereis, H. Schlager, H., Schulte, P., van Velthoven, P., and Slemr, F.: Distributions of $\mathrm{NO}, \mathrm{NO}_{\mathrm{x}}$, and $\mathrm{NO}_{\mathrm{y}}$ in the upper troposphere and lower stratosphere between $28^{\circ}$ and $61^{\circ} \mathrm{N}$ during POLINAT 2, J. Geophys. Res., 105, 3653-3664, 2000. 
Zöger, M., Afchine, A., Eicke, N., Gerhards, M.-T., Klein, E., McKenna, D. S., Mörschel, U., Schmidt, U., Tan, V., Tuitjer, F., Woyke, T., and Schiller, C.: Fast in situ stratospheric hygrometers: A new family of balloon-borne and airborne Lyman- $\alpha$ photofragment fluorescence hygrometers, J. Geophys. Res., 104, 1807-1816, 1999. 